\section{Ankara Üniversitesi Eğitim Bilimleri Fakültesi Özel Eğitim Dergisi}

2022, 23(1), 53-83
ARAŞTIRMA

Gönderim Tarihi: 22.06 .20

Kabul Tarihi: 06.04.21

Erken Görünüm: 26.04.21

\title{
Zihin Yetersizliği Olan Bireylere Kişisel Bakım Becerilerinin Öğretiminde Bir Aile Eğitimi Programının Etkililiği*
}

\author{
Seniha Kurtoğlu $\mathbb{D} 1$
}

\author{
Atilla Cavkaytar (iD)2
}

Öz

Giriş: Kişisel bakım becerileri bireylerin kendi kendilerine yetebilmelerinde kritik öneme sahiptir. $\mathrm{Bu}$ araştırmanın amacı annenin kişisel görüş noktası tekniğini kullanılarak öğretim sunma becerilerini içeren aile eğitim programının etkililiğini belirlemektir.

Yöntem: Araştırma, 18 yaşında, zihin yetersizliği (ZY) olan birey ve bireyin 42 yaşındaki annesiyle gerçekleştirilmiştir. Tek denekli araştırma modelleri içerisinde yer alan davranışlar (beceriler) arası yoklama evreli çoklu yoklama modeli kullanılarak yürütülen bu araştırmanın bağımsız değişkeni "Zihin Yetersizliği Olan Bireylere Kişisel Bakım Becerilerinin Öğretimi” adlı aile eğitimi programı ve annenin bu program doğrultusunda ZY olan çocuğuyla birlikte yürüttüğü öğretim çalışmaları iken bağımlı değişkeni ZY olan bireyin hedeflenen kişisel bakım becerilerini yerine getirme düzeyleridir.

Bulgular: Araştırmanın sonucunda ZY olan bireyin annesi tarafından kendisine öğretilen kişisel bakım becerilerini kazandığı, bu becerileri farklı ortamlara, farklı kişilere, farklı araç-gereçlere genellediği görülmüştür. Ayrıca birey öğrendiği becerileri öğretim sona erdikten sonra da devam ettirmiştir. Anne de kişisel görüş noktası tekniğini uygun ve güvenilir șekilde kullanmıştır. Programa ilişsin elde edilen sosyal geçerlik verileri annenin aile eğitim programına katılmaktan ve kızına kişisel bakım becerilerini (tırnak bakımı, ped kullanma ve saça şekil verme) kazandırabilmiş olmaktan dolayı memnun olduğunu göstermiştir.

Tartışma: Bu araştırmanın bulguları alanyazındaki çalışmaların sonuçlarını destekler niteliktedir. Videoyla model olma türlerinden biri olan kişisel görüş noktası tekniği kullanılarak yapılan öğretim sonucunda öğretimi yapılan tüm kişisel bakım becerilerinde bireyin performansında ilerlemelerin olduğu görülmüştür.

Anahtar sözcükler: Zihin yetersizliği, aile eğitimi, kişisel bakım becerileri, videoyla model olma, kişisel görüş noktası tekniği.

Atıf için: Kurtoğlu, S., \& Cavkaytar, A. (2022). Zihin yetersizliği olan bireylere kişisel bakım becerilerinin öğretiminde bir aile eğitimi programının etkililiği. Ankara Üniversitesi Eğitim Bilimleri Fakültesi Özel Ĕ̈itim Dergisi, 23(1), 53-83. https://doi.org/10.21565/ozelegitimdergisi.756223

\footnotetext{
*Bu çalışma ZEÖ605 Uygulamalı Aile Eğitimi dersi kapsamında hazırlanmış ve 29. Ulusal Özel Eğitim Kongresinde sözlü bildiri olarak sunulmuştur.

${ }^{1}$ Sorumlu Yazar: Öğretmen, Özel Eğitim Meslek Okulu, E-posta: senihakurtoglu37@gmail.com, https://orcid.org/0000-00022222-1029

${ }^{2}$ Prof. Dr., Maltepe Üniversitesi, Eğitim Fakültesi, Özel Eğitim Bölümü, E-posta: atillacavkaytar@maltepe.edu.tr, https://orcid.org/0000-0001-8067-1602
} 


\section{Giriş}

Zihin yetersizliği (ZY) olan bireylerin eğitim öğretim süreçlerindeki amaç bu bireylerin eğitim ihtiyaçları ve yeterlilikleri dikkate alınarak, performanslarını mümkün olduğunca üst düzeyde kullanmaları, üst öğrenime, istihdam sürecine ve toplumsal yaşantıya hazırlanmalarıdır (Özel Eğitim Hizmetleri Yönetmeliği [ÖEHY], 2018). $\mathrm{Bu}$ bağlamda $\mathrm{ZY}$ olan bireylere bağımsız yaşam becerilerini kazandırmak gerekmektedir. Bağımsız yaşam becerilerinin bu bireylere kazandırılması onların yaşam kalitelerini arttırmaya yardımcı olmak, bireylerin halihazırda sergiledikleri becerileri geliştirmek anlamında oldukça önemlidir (Cavkaytar, 2000).

Bağımsız yaşam becerileri kapsamında günlük yaşam becerileri, öz belirleme/kişisel-sosyal becerilerle mesleki rehberlik ve mesleğe hazırlık becerileri yer almaktadır (Brolin, 1997; Orum-Çattık \& Ergenekon, 2019; Wandry vd., 2013). Bu beceriler, bağımsız bir șekilde yaşantıyı sürdürmek, uygun görünme ve bakımlı olmak için gerekli olan becerilerdir (Varol, 2004). Bağımsız yaşam becerilerinin içerisinde kişisel bakım becerilerini de içeren öz bakım becerileri yer almaktadır. Öz bakım becerileri tuvalet, beslenme, giyinme gibi en temel düzeydeki öz bakım becerileri; el ve yüz yıkama, diş firçalama ve diş bakımı, banyo yapma, saç tarama gibi temel becerileri destekleyen nitelikteki beceriler; tırnak kesme, cilt ve saç bakımı yapma, menstüral beceriler gibi kişisel bakım becerileri ve giysilerin seçimi, ilaçları uygun şekilde alma, sağlıklı beslenme ve cinsel yaşam için gerekli beceriler gibi ileri düzey öz bakım becerilerinden oluşmaktadır (Brolin, 1997; Wandry vd., 2013).

Özel gereksinimi olan bireylerin öz bakım becerilerini belli düzeyde yerine getirmeleri onların toplum tarafından kabul görmelerine ve bağımsız yaşamalarına büyük ölçüde katkı sağlayacağından bu becerilerin bu bireylere kazandırılması oldukça önemlidir. Bu bağlamda ZY olan bireylerin programlarında bu becerilerin kazandırılmasına yönelik eğitsel ve öğretimsel düzenlemelere yer verilmektedir. Bağımsız yaşam becerileri içerisinde yer alan öz bakım becerilerinin öğretimine yönelik uygulamalar incelendiğinde (a) ipucunun giderek arttırılmasıyla öğretim (ör. Cavkaytar, 1998); (b) ipucunun giderek azaltılmasıyla öğretim (ör. Özen vd., 2002); (c) davranış öncesi ipucu ve sınamayla öğretim (ör. Ersoy, 2005); (d) videoyla model olma öğretim uygulamaları (ör. Çakmak, 2011; Hagiwara \& Myles, 1999; Öncül \& Yücesoy-Özkan, 2010); (e) eş zamanlı ipucuyla öğretim (Okyar \& Çakmak, 2009); (f) sabit bekleme süreli öğretim ve ipucunun sistematik olarak geri çekilmesi işlem süreci (Aykut \&Varol, 2010); (g) şarkı yoluyla öğretim (Ünal vd., 2016); (h) mobil beceri öğretimi taslak yazılımı (ör. Çankaya, 2013) gibi pek çok yöntemin kullanıldığ ve kullanılan yöntemlerin etkili olduğu görülmektedir. Bu etkili uygulamalardan bir tanesi olan video teknoloji uygulamaları videoyla kendine model olma (video selfmodeling), (b) video geribildirimi (video feeedback), (c) videoyla model olma (video modeling), (d) bilgisayar destekli video öğretimi (computer-based video instruction), (e) etkileşimli video ipucu/video öğretimi (interactive video instruction/video prompting), (f) kişisel görüş noktası (subjective point of view) olarak sınıflanmaktadır (Mechling, 2005).

ZY olan bireylerin eğitim-öğretim faaliyetlerinde video teknolojilerinden biri olan videoyla model olma yönteminin sıklıkla kullanıldığı görülmektedir (ör. Çakmak, 2011; Hagiwara \& Myles, 1999; Öncül \& YücesoyÖzkan, 2010). Çakmak (2011) video teknolojisi türlerinden biri olan videoyla model olma tekniğini kullandığı çalışmasında oluşturduğu aile eğitimi programının, araştırmanın katılımcıları olan annelerin, öz bakım becerilerini öğretmede yer alan basamakları uygulama düzeylerinde etkili olup olmadığına bakmıştır. Aynı zamanda araştırmacı anneleri tarafından sunulan öğretimin görme engelli çocukların öğretilen öz bakım becerilerini sergileme düzeyleri ve sergiledikleri becerileri sürdürme düzeylerindeki etkililiğini belirlemeyi de amaçlamıştır. Araştırmanın bulguları aile eğitim programını tamamlayan annelerin çocuklarına videoyla model olarak sundukları öz bakım becerilerini öğretebilme basamaklarını gerçekleştirdikleri; çocukların ise kendilerine öğretilen becerileri edindikleri ve sürdürdükleri görülmüştür. Yürütülen bu araştırmada da video teknolojisi kullanılarak, öz bakım becerilerinin aileler tarafından çocuklarına öğretilmesi söz konusudur. Çakmak'ın (2011) çalışmasından farklı olarak bu araştırmada video teknoloji tekniklerinden biri olan kişisel görüş noktası kullanılmıştır. Bu teknik, öğrencinin beceri ya da davranışları kendisinin sergilediği şekliyle, öğrencinin göz hizasından ya da görüş hizasından kaydedilerek kullanılmasıdır (Mechling, 2005; Öncül \& Yücesoy-Özkan, 2010; Shipley-Benamou vd., 2002). Oluşturulan kayitlarda model yer almamakta, video kamera bir izleyiciye benzer şekilde hareket etmektedir. Ayrıca Çakmak (2011) çalışmasında öz bakım becerilerinden kazak giyme, pantolon giyme, ayakkabı giyme, kaşıkla yemek yeme gibi farklı alanlardaki (giyinme ve yemek yeme) öz bakım becerilerine yer verirken bu araştırma kapsamında öz bakım becerilerinden sadece kişisel bakım becerilerinin öğretimine yer verilmesi de farkı ortaya koymaktadır.

Tipik gelişen bireylerin eğitim sürecinde olduğu gibi ZY olan bireylerin eğitim öğretim sürecinde de eğitim-öğretim faaliyetleri ZY olan birey, bireyin ailesi ve bireyin eğitim aldığı kişi olmak üzere temelde bu üçgen 
etrafında yoğunlaşmaktadır. ZY olan bireyler, zamanlarının çok büyük bir bölümünü ev veya toplumsal ortamlarda, aileleriyle birlikte geçirmektedirler. Geçirilen bu vakitlerin verimli olması, farklı ve yeni becerilerin öğrenilmesi, okulda öğrenilen becerilerin evde tekrarlanması (genellenmesi) ve kalıcılığının sağlanması ailenin sürece aktif katılımıyla ve ek uyarlamalar yapılmasıyla mümkün olmaktadır. Bunlara ek olarak çocukları en iyi tanıyan kişiler yine onların aileleridir. Dolayısıyla eğitim-öğretim sürecinde nitelikli ve uygun eğitim olanakları sağlandığı zaman ve ailelerin sürece katılımıla formal ve informal olarak öz bakım becerileri özel gereksinimi olan bireylere kazandırılabilir (Aydın \& Cavkaytar, 2019; Purpura vd., 2013; Shanley vd., 2017; Skwarchuk vd., 2014).

Öz bakım becerileri günlük hayatta ev içerisinde çocuğun cinsiyetine göre anne/baba, abi/abla desteğiyle spontan bir şekilde gerçekleştirilebileceği gibi, sistematik bir öğretimsel süreç içerisinde de gerçekleştirilebilir (Aydın \& Cavkaytar, 2019). Aile üyelerinin çocuklarına sistematik öğretim sunabilmeleri için aile eğitimi hizmetlerinden yararlanmaları gerekmektedir. Bu kapsamda ailelere aile eğitimi hizmetleri sunulmaktadır. Aile eğitimi, anne ve babalara çocuklarının özellikleri konusunda bilgi sunmak, onlara çocuklarına farklı konularda gereksinim duydukları bilgi ve becerileri nasıl kazandıracaklarını öğretmek, çocuklarının olumlu davranışlarını nasıl arttıracakları ya da olumsuz davranışlarında nasıl azaltma/yok etme yoluna gidecekleri konusunda öğretimler yapmak maksadıyla gerçekleştirilmektedir (Patterson vd., 2012).

Alanyazında ailelerin çocuklarının eğitiminde uygulamacı olarak yer aldığı, çocuklarına öğretici oldukları çok sayıda araştırmaya rastlanmaktadır. Bu araştırmalardan bazıları ZY olan bireylere bağımsız yaşam becerileri (Welterlin vd., 2012); öz bakım ve ev içi becerileri (Cavkaytar, 1998; Cavkaytar ve Pollad 2009); öz bakım becerileri (Batu vd., 2014; Çakmak, 2011); günlük yaşam becerileri (Doğan, 2010); gündüz tuvalet kontrolü (Özkubat \& Töret, 2014; Sönmez, 2008; Sönmez \& Varol, 2009); bağımsız tuvalet becerileri (Özcan, 2004; Sönmez \& Aykut, 2011); ev içi becerileri (Batu, 2008; Ulugöl \& Cavkaytar, 2020); davranış kontrolü (Tavil, 2005); etkileşimsel davranışlar (Karaaslan, 2010); kurallar (Boyraz, 2015); sosyal beceriler (Acar, 2015); aile içi ve toplumsal etkileşim becerileri (Gökçe, 2017); iletişim becerileri (Douglas vd., 2017); toplumsal yaşam becerilerinin (Tekin-İftar, 2008) kazandırılmasına yönelik aile eğitim programlarını kapsayan araştırmalardır.

Alanyazında da görüldüğü üzere ZY olan bireylerin eğitiminde aile katılımının gerekliliğinin vurgulanmasına rağmen söz konusu bireylerin bağımsızlı̆g i için temel beceri olarak nitelenen, kişinin hijyeni, sağlık durumu, estetik görünümü açısından önemli olan kişisel bakım becerilerinin aileler tarafından öğretiminin yapıldığı araştırmalar sınırlıdır. Ayrıca ZY olan bireylere kişisel görüş noktası tekniği kullanılarak sunulan kişisel bakım becerilerinin aileler tarafından kazandırıldığı herhangi bir araştırmaya ulaşılmamış olması da araştırma sınırlılığını açıklamaktadır. Araştırma kapsamında bulunan ped değiştirme ve koltuk altı tüy alma becerilerinin okul ortamında çalışılması zor olacağından ev ortamında ve bireyin ailesi tarafından öğretiminin yapılması daha uygun olacaktır.

$\mathrm{Bu}$ araştırmadan elde edilen sonuçların uzman kişiler, öğretmenler ve anne-babalar için gerek kuramsal gerekse de uygulama açısından büyük önem taşıyacağı düşünülmektedir. Kişisel bakım becerilerini de içeren öz bakım becerilerinin edinimi bireyin bağımsız bir yaşam sürdürmesi ve yaşam kalitesinin artmasına katkı sunacaktır. Kişisel bakım becerilerinin öğretimi aile eğitim programının ailelerin evde çocuklarına hangi becerileri nasıl öğretecekleri konusundaki bilgi gereksinimlerinin bir kısmının karşılanmasına katkı sağlayacağı, farklı araştırmalara örnek teşkil edip kaynak oluşturacağı ve gerek ulusal gerekse de uluslararası alanyazını genişletip katkı sağlayacağı öngörülmektedir. Bu nedenlerden dolayı araştırmaya olan gereksinim yadsınamaz. Buradan hareketle bu araştırmanın amacı annenin kişisel görüş noktası tekniği kullanılarak öğretim sunma becerilerini içeren aile eğitim programının etkililiğini belirlemektir. Bu doğrultuda araştırmada şu sorulara yanıt aranmıştır:

1. Aile eğitim programı annenin kişisel görüş noktası tekniği ile öğretim sunmasında etkili midir?

2. Annenin çocuğuna sunduğu öğretim, çocuğun kişisel bakım becerilerini edinmesinde etkili midir?

3. Anne ve çocuğu edindikleri bu becerileri öğretimin sona ermesinden bir, iki ve üç hafta sonrasında koruyabilirler mi?

4. ZY olan birey edindiği bu becerileri farklı toplumsal ortamlar, farklı kişiler ve farklı araç-gereçlere genelleyebilir mi?

5. Uygulama aşamasına yönelik olarak annenin görüşleri nelerdir? 


\section{Yöntem}

\section{Araştırma Modeli}

Yürütülen bu araştırmada annenin kişisel görüş noktası tekniği kullanarak öğretim sunma becerilerini içeren aile eğitim programının etkililiğini değerlendirmek amaçlanmıştır. Bu amaçla araştırmada tek-denekli araştırma modellerinden davranışlar (beceriler) arası yoklama evreli çoklu yoklama modeli kullanılmıştır. Çoklu yoklama modelleri içerisinde yer alan yoklama evreli çoklu yoklama modeli deseninde bütün durumlarda (ör. tüm becerilerde) aynı anda başlama düzeyi verisinin toplanıp, ilk durumda (beceride/davranışta) kararlı veri elde edildiğinde bu evre sonlandırılır. İlk durumda (beceride/davranışta) uygulama sürecine geçilir ve öğretime başlanır. Birinci durumda (beceride/davranışta) uygulama evresi devam ederken, ikinci ve üçüncü durumda (beceride/davranışta) herhangi bir veri toplaması yapılmaz. Birinci durumda (beceride/davranışta) ölçüt karşılanarak kararlı veri elde edildiğinde, bütün durumlarda (becerilerde/davranışlarda) aynı anda birinci yoklama evresi düzenlenir. Birinci yoklama evresi sırasında ikinci durumda (beceride/davranışta) kararlı veri elde edildiğinde ise söz konusu yoklama evresi sonlandırılır. Ardından ikinci durumda (beceride/davranışta) öğretime başlanır. Bu aşamadaki süreç bütün davranışlar için ölçüt karşılanana kadar aynı şekilde sürer (Tekin-İftar, 2012).

$\mathrm{Bu}$ araştırmada iki bağımlı değişken yer almaktadır. Birincisi, "araştırmanın katılımcısı annenin kişisel bakım becerilerini öğretme becerisinde yer alan beceri basamaklarını gerçekleştirme düzeyi”; ikincisi "ZY olan bireyin annesi tarafından kendisine öğretilen tırnak bakımı, ped kullanma, koltuk altı tüy alma gibi kişisel bakım becerilerini edinme ve edindikleri becerileri sürdürme düzeyleridir”. Geliştirilen aile eğitimi programı ve annenin bu program doğrultusunda kızıyla birlikte gerçekleştirdiği öğretim çalışmaları ise araştırmanın bağımsız değişkenleridir.

\section{Katılımcilar}

Araştırma katılımcılarının belirlenmesi için araştırmacı görev yaptığı okul olan Özel Eğitim Meslek Okulu'ndaki özel eğitim öğretmenleriyle görüşmüş, onlara araştırması hakkında bilgi vermiş ve bu kapsamda aile eğitimine ihtiyacı olan ailelerin numaralarını edinmiştir. Ardından araştırmacı iletişim bilgilerini aldığı ailelerle iletişime geçmiştir. Ailelerden araştırmaya katılmayı isteyenlerle bire-bir, yüz yüze görüşme gerçekleştirmiştir.

Yürütülen bu araştırmaya katılımda katılımcılardan birtakım özelliklere sahip olmaları beklenmektedir: Araştırmanın katılımcısı olan bireyin; (a) motor beceri ve davranışları sergilemelerine engel olacak herhangi bir fiziksel yetersizliğe sahip olmaması, (b) taklit becerilerine sahip olması, (c) bekleme becerisine sahip olması, (d) çoklu yönergeleri yerine getiriyor olması beklenmiştir. Aile Eğitim Programı'na katılmak için katılımcı aile bireyinden ise (a) çalışma için vakit ayırması, (b) ZY olan çocuğa sahip olması, (c) önceden başka bir aile eğitim programına dahil olmamış olması, (d) aile eğitimi programındaki gerekli olan bütün eğitim-öğretim süreçlerine katılmayı onaylaması, (e) okuma ve yazma becerisine sahip olması gibi özellikleri karşılaması beklenmiştir. Anneye program içeriğinden söz edilmiş ve anneden gönüllü katılımcı onam formunu sesli olarak okuması ve imzalaması talep edilmiştir. Araştırmada katılımcıları çağrıştıran kod isimler kullanılmıştır. Aşağıda katılımcıların özellikleri şöyle sıralanmaktadır:

Anne Nazik Hanım 42 yaşındadır. Araştırma için belirlenen ön koşulları taşımaktadır. Ortaokul mezunudur, ev hanımıdır. Çocuğu Sevgi ise 18 yaşında, hafif düzeyde ZY gösteren bir kadındır. Sevgi, taklit becerilerine sahiptir. Akademik becerilerden okuma ve harf taklit etme becerisine sahip fakat yazma becerisinde desteğe ihtiyaç duymaktadır. Birden 20'ye kadar sayma, miktar kavramlarına sahiptir fakat saat okuma, parayı ayırt etme ve kullanma becerilerinde desteğe ihtiyaç duymaktadır. Sevgi, basit ev içi becerilerini (yatak-dolap düzeltme, toz alma, bulaşıkları makineye yerleştirme) yerine getirmektedir fakat toplum kaynaklarını kullanma (otobüs kullanma, bankamatikten para çekme, fatura yatırma, yemek siparişi verme vb.), kişisel bakım becerilerinden banyo yapma, saç bakımı yapma, tırnak kesme, beden temizliği yapma (tüylerin alınması) gibi becerileri yerine getirmede desteğe ihtiyaç duymaktadır.

Araştırmanın katılımcıları dışında araştırmacı, araştırmacı yardımcısı ve gözlemci de araştırmaya destek veren diğer katılımcılardır. Araştırmada aile eğitimi programı araştırmacı tarafından yürütülmüş, güvenirlik verileri bir özel eğitim uzmanı tarafından toplanmış, video kayıtları araştırmacı yardımcısı tarafından gerçekleştirilmiştir. Araştırmacı ve güvenirlik verilerini toplayan uzman zihin engellilerin eğitimi doktora programı öğrencileridir. Aynı zamanda uzmanlar Milli Eğitim Bakanlığına (MEB) bağlı bir özel eğitim meslek okulunda özel eğitim sınıf öğretmeni olarak on yıldır görev yapmaktadırlar. Araştırmacı ve güvenirlik verilerini toplayan bu uzmanlar tek denekli araştırma konusunda bilgi sahibi olup lisanüstü eğitimde bu dersi almışlardır. 
Araştırmacı öğretilmesi planlanan tırnak bakımı, ped kullanma, koltuk altı tüy alma gibi kişisel bakım becerilerini belirledikten sonra becerilerin öğretiminin yapılacağı ortama karar vermiştir.

Araştırmada yer alacak becerilerin öğretimi kapsamında bireyin mahremiyetini korumak amacıyla ped kullanma becerisinde öğrenciye kıyafet olarak tayt ve tayt üzerine de külot giydirilmiştir. Bunun dışında öğretimlerin öğrencinin regl dönemlerinin dışındaki dönemlerde gerçekleştirilmesi planlanmıştır. Koltuk altı tüy alma becerisinde ise öğrenciye kolsuz bir tişört giydirilerek ve bireye temas gerektirmeyen materyaller (köpük, sünger, spatula vb.) kullanılarak bu becerinin öğretiminin yapılmasına karar verilmiştir.

Ortama ve becerilerin nasıl öğretileceğine karar verildikten sonra bu ortamlarda yoklama (günlük ve toplu yoklama), ögretim, izleme, genelleme oturumları sırasında ses ve görüntü kaydı alınması konusunda resmi izinler almıştır. Ayrıca araştırmacı katılımcılardan çalışmaya gönüllü olarak katıldıklarına dair katılımcı onam formu almıştır. Araşırmacı bu süreçte uygulamanın gerçekleştirileceği ortamlar için gerekli izinleri alarak araştırmanın yürütülmesi ve ileriki dönemlerde yayımlanması için Etik Kurul onay dokümanlarını da hazırlamıștır. Araştırmacı düzenlediği etik kurul dokümanlarıyla Anadolu Üniversitesi Etik Kurul Başkanlığına başvuruda bulunmuş ve etik kurul onayı (13.03.2019 evrak kayıt tarihli, 21574 protokol nolu, 28.03.2019 tarihli) ile çalışmasını yürütmüştür.

\section{Veri Toplama Araçları}

Aile eğitimi programının başarısını değerlendirmek için "Aile Eğitim Program Amaçlarını Değerlendirme Ölçü Aracı” (bk. Ek A) kullanılarak annenin Kişisel Bakım Becerileri Aile Eğitim Programı'na yönelik performansına ilişkin ön test ve son test verileri toplanmıştır. Etkililik verilerini toplama aşamasında aile eğitimi programı kapsamında çalışılması belirlenen becerilerin beceri basamakları yazılarak beceri basamaklarının hemen yanına oturumlarda elde edilen verileri işaretlemek üzere sütunlar ilave edilmiştir. Öğretimi yapılan tüm beceriler için de benzer şekilde "Yoklama Oturumları Veri Kayıt Formları" (bk. Ek C) oluşturulmuştur. Hazırlanan bu formlar aynı zamanda gözlemciler arası güvenirlik verileri toplama aşamasında da kullanılmıştır. Sosyal geçerlik verilerinin toplanması için de "Anne Sosyal Geçerlilik Soru Formu” (bk. Ek D) kullanılmıştır.

\section{Aile Eğitimi Programının Geliştirilmesi}

Kişisel Bakım Becerilerinin Öğretimi Aile Eğitimi Programı ZY olan çocuğa sahip anneyi çocuğuna evde kişisel bakım becerilerini öğretmede yeterli duruma getirmeyi amaçlamaktadır. Programda ebeveynleri öğretici olarak gören yaklaşım benimsenmiştir. Bu amaca yönelik olarak yüz yüze eğitim etkinliklerini içeren anne toplantıları ve ev ziyaretleri aşamalarına programda yer verilmiştir.

$\mathrm{Bu}$ aşamaların uygulanmasında, oluşturulan programda yer alan amaçlar doğrultusunda hazırlanan Kişisel Bakım Becerilerinin Öğretimi El Kitabı esas alınmıştı (Tablo 1). Programın amaçları doğrultusunda geliştirilen ve içerikteki konulara ilişkin açıklama ve uygulamaların yer aldığı, ailelere hitap edecek biçimde yazılı olarak sunulan bu kitap Cavkaytar'ın (1998) öz bakım ve ev içi becerilerinin edinimini ailelere kazandırmayı amaçladığı doktora tez çalışmasından uyarlanmıştır.

Uygulama aşamasında ailenin öğrendiği bilgileri kullanarak çocuğuna uygulamacı gözetiminde örnek beceride (saça şekil verme) bir öğretim sunması, günlük yoklama oturumu gerçekleştirmesi ve video kaydına alınan bu süreçlerin tartışılarak dönüt ve düzeltmelerle netleştirilmesi amaçlanmış, bu doğrultuda süreç planlanmıştır. Programda yer alan anneyle yapılan toplantılar aile eğitimi programı içeriğinin sunulmasına yönelik uzman rehberliğinde yapılan yüz yüze toplantılardan, ev ziyaretleri ise araştırmacının anneyle ev ortamında birebir yaptıkları çalışmalardan oluşmaktadır. Öğrenme-öğretme süreçlerinde kişisel görüş noktası tekniğine yer verilmiştir. 
Tablo 1

Kişisel Bakım Becerilerinin Öğretimi El Kitabı İçeriği

\begin{tabular}{|c|c|c|c|}
\hline $\begin{array}{c}\text { 1. Bölüm } \\
\text { Temel düzey bilgiler }\end{array}$ & $\begin{array}{c}\text { 2. Bölüm } \\
\text { Beceri öğretimine hazırlık }\end{array}$ & $\begin{array}{c}\text { 3. Bölüm } \\
\text { Beceri öğretimi }\end{array}$ & $\begin{array}{c}\text { 4. Bölüm } \\
\text { Örnek beceri öğretimi }\end{array}$ \\
\hline $\begin{array}{l}\text { Bağımsı̈ı yaşam, } \\
\text { günlük yaşam, öz } \\
\text { bakım ve kişisel } \\
\text { bakım becerilerine } \\
\text { ilişkin bilgiler yer } \\
\text { amaktadır. }\end{array}$ & $\begin{array}{l}\text { Bireyin performansı, gereksinim } \\
\text { duyulan beceriler ve becerilerin } \\
\text { öncelik sırası ve kullanılacak } \\
\text { pekiştireçleri belirleme, öğretimsel } \\
\text { çalışmaları planlama (becerinin } \\
\text { adı, çalışmanın amacı, yeri, } \\
\text { öğretim materyalleri ve öğretim } \\
\text { videolarını hazırlama, beceri } \\
\text { analizi oluşturma, kişisel görüş } \\
\text { noktası tekniğini açıklama) } \\
\text { konularına ilişkin açıklama ve } \\
\text { örnek uygulamalar yer almaktadır. }\end{array}$ & $\begin{array}{l}\text { Çalışma yer ve zamanları, } \\
\text { süresi, öğretimden önceki } \\
\text { hazırlıklar, öğretim anındaki } \\
\text { çalışmalar (bireyin dikkatini } \\
\text { çekme, bireye beceri } \\
\text { yönergesini sunma, } \\
\text { ipuçlarının türleri, ipuçlarını } \\
\text { sunma, ipuçları sıralaması, } \\
\text { pekiştirme, onaylama, } \\
\text { harekete geçirme) konularına } \\
\text { ait bilgilendirmeler yer } \\
\text { almaktadır. }\end{array}$ & $\begin{array}{l}\text { Örnek beceri öğretimi } \\
\text { uygulamaları yer } \\
\text { almaktadır. }\end{array}$ \\
\hline
\end{tabular}

\section{Verilerin Toplanması}

$\mathrm{Bu}$ araştırmada Sevgi'nin öğretimi gerçekleştirilecek becerilerdeki halihazırdaki performanslarına yönelik verileri (yoklama verileri) elde etmek için performans alım sürecinde yararlanılan bir yöntem olan tek firsat yöntemi kullanılmıştır. Tek firsat yöntemiyle veri toplanırken, bireye beceriye ilişkin beceri yönergesi sunulur ve bireyin tepkileri yoklama oturumları veri kayıt formundaki doğru/yanlış tepkiler sütununa uygun başlık altına işaretlenir. Bireyin beceriyi sergilerken ilk "_” aldığı basamakta değerlendirme sonlandırılıp beceri analizinde yer alan sonraki beceri basamakları yoklama oturumları veri kayıt formuna yanlış tepki şeklinde işaretlenir. Tüm yoklamalara ait oturumlarda bu süreç takip edilir. Başlama düzeyi verisi toplanıp kararlı veri elde edildikten sonra becerinin öğretimine geçilir (Tekin-İftar, 2012). Öğretim oturumlarında aşağıda detaylı bir şekilde açıklanan kişisel görüş noktası tekniği kullanılmıştır. Öğretim öncesinde gerçekleşen günlük yoklama oturumlarında veri toplama süreci performans alımı sürecinde izlenen yol takip edilerek gerçekleştirilmiştir.

Genelleme oturumlarına yönelik toplanan verilerde ise ön-test son- test uygulamasıyla değerlendirilme yapılmıştır. Bu aşamadaki oturum süreçlerinde toplu yoklama oturumlarındaki gibi bir yol takip edilmiştir. Öntest ve son-test şeklinde düzenlenen genelleme oturumlarına ait tüm oturumlarda önceki oturumlarda kullanılanlardan farklı kişiler, farklı ortamlar, farklı araç-gereçler ve beceriye göre değişen becerinin farklı bir boyutu (ayak tırnağı, günlük ped, bikini bölgesi veya bacak tüylerini alma gibi.) kullanılarak süreç yürütülmüştür. Genelleme oturumlarında anne çocuğunun performansını etkinliğin sonunda sözel ifadeler sunarak (ör. "Çok güzel çalışıı kızım, aferin sana!”) pekiştirmiştir.

Araştırmanın son aşaması olan izleme oturumları ise evde, öğretimi yapılan bütün becerilerde ölçütün karşılanmasının ardından bir, iki, üç hafta sonra düzenlenmiştir. İzleme oturumlarında izlenen süreç yoklama oturumlarına paralellik göstermektedir. ZY olan birey beceriye ait tüm basamakları doğru biçimde gerçekleştirdiğinde, oturum sona erdikten sonra sözel olarak ve sosyal pekiş̧ireçler kullanılarak pekiştirilmiştir (ör. "Aaa çok güzel yaptın kızım, aferin benim kızıma", "Çak şeklindeki işareti yapma" vb.). Bunun dışında uygulamanın izleme oturumlarının sona ermesinden bir, iki ay sonra da çocuğun beceriyi sergilediği uzman tarafından gözlemlenmiştir.

Araştırmada gözlemciler arası güvenirlik verileri ve uygulama güvenirliği verileri olmak üzere iki çeşit güvenirlik verisi toplanmıştır. Araştırmada başlama düzeyi, yoklama (günlük ve toplu yoklamalar) ve izleme oturumlarının tamamı videoyla kayıt altına alınmıștır. Annenin yürütmüş olduğu oturumlardan yansız atama yoluyla belirlenen oturumların \%20'si, özel eğitim alanında uzman olan bir gözlemci tarafindan izlenerek güvenirlik verileri toplanmıştır. Gözlemciye bu süreçte neler yapması gerektiği konusunda açıklama yapılmıştır. Gözlemciler arası güvenirlik verilerinin toplanmasında video kayıtlarını izleyen gözlemci, katılımcı bireyin becerileri oluşturan davranışları sergileyip sergilemediğini " +/_" șeklinde önceden düzenlenmiş olan veri toplama kayıt formuna işaretlemiştir. Gözlemcinin kayıtları araştırmacının kayıtlarıyla karşılaştırılarak değerlendirmenin tutarlılığı heseplanmıştır.

Gözlemciler arası güvenirlik verilerinin ortalamalarına bakıldığında tırnak bakımı becerisinde \%95.6 ( $\mathrm{ranj}=\% 80-\% 100)$, ped kullanma becerisinde $\% 97(\mathrm{ranj}=\% 85-\% 100)$, koltuk alt tüy alma becerisinde $\% 97$ (ranj = \% 85-\%100) olarak belirlenmiştir. Araştırmada annenin çocuğuna kişisel görüş noktası tekniğini kullanarak kişisel bakım becerilerini doğru şekilde uygulayıp uygulamadığını görmek için uygulama güvenirliği verisi 
toplanmıştır. Araştırma kapsamında elde edilen uygulama güvenirliği verileri gözlemcinin rasgele belirlediği oturumların \%20'sini içeren video kayıtlarını izleyerek, annenin öğretim sürecine ilişkin uygulama oturumlarını planladığı gibi uygulayıp uygulamadığını değerlendirmesi yoluyla belirlenmiştir. Gözlemci gerçekleştirdiği değerlendirmede "Annenin Gerçekleştirdiği Uygulama Güvenirliği Veri Kayıt Formunu" kullanmıştır. Uygulama güvenirliği verilerinin ortalamaları tırnak bakımı becerisi için \%93.6 ( $\mathrm{ranj}=\% 80-\% 100)$, ped kullanma becerisi için \%93.6 (ranj $=\% 80-\% 100)$, koltuk altı tüy alma becerisi için \%92 (ranj = \% 80-\%100) olarak belirlenmiştir. Araştırmada araştırmacının yürüttüğü uygulama ise "Aile Eğitim Programı Uygulama Kontrol Listesi ” (bk. Ek B) kullanılarak değerlendirilmiştir. Araştırmada araştırmacının yürüttüğü uygulamayı doğru şekilde yürüttüğü görülmüştür.

Araştırmanın öğretim süreci sona erdikten sonra anneden aile eğitim programı, kişisel görüş noktasıyla öğretim ve öğretim sonucunda elde edilen bulgulara ilişkin sosyal geçerlik verisi elde edilmiştir. Sosyal geçerlik verilerinin elde edilmesinde araştırmacı tarafından geliştirilen "Anne Sosyal Geçerlik Soru Formu" kullanılmıştır. Bu form Cavkaytar'ın (1998) ailelere çocuklarına öz bakım ve ev içi becerilerinin edinimini kazandırmayı amaçladığı doktora tez çalışmasından faydalanarak hazırlanmıştır.Veriler anne ile doğrudan görüşme yapılarak toplanmıştır.

\section{Uygulama Süreci}

Araştırmanın uygulama sürecinde anneye verilen eğitim çocuğun devam ettiği okulda yürütülmüş, ayrıca ev ziyaretleri ve telefon görüşmelerine yer verilmiştir. Bu şekliyle uygulanan program kuruma ve eve dayalı olarak sürdürülmüş bir programdır. Araştırmanın uygulama süreci anneyle yapılan toplantılarla başlamıştır.

Yüz yüze eğitim etkinliklerinden oluşan anneyle yapılan toplantıların her biri bir saat sürmüştür. Ayrıca ZY olan bireyin evinde bir buçuk saat süren bir ev ziyareti gerçekleştirilmiş̧tir. Ev ziyaretlerine ek olarak telefon görüşmeleri de yapılmıştır. Telefon görüşmeleri, ailenin çocuğuyla çalışmaları sırasında tereddüt ettiği ya da kararsız kaldığı durumları uzmana danışma, becerinin öğretimi tamamlandığında uzmana haber verme, uzmanın ailenin çalışmasını takip etme amacıyla yapılan görüşmeleri kapsamaktadır. Toplantı ve ev ziyareti annenin çocuğuna kişisel bakım becerilerinin öğretimi için belirlenen amaçlarda yeterli duruma gelinceye kadar sürdürülmüştür.

Anne için düzenlenen toplantılar öğrencinin devam ettiği kurumda düzenlenen bir derslikte yapılmıştır. Anneye kişisel görüş noktası tekniği kullanarak çocuğuna kişisel bakım becerilerini nasıl öğreteceği konusunda öğretim sunulmadan önce annenin program amaçlarını kazanma düzeyi belirlenmiştir. Bu aşamada "Aile Eğitim Program Amaçlarını Değerlendirme Formu" kullanılmıştır. Değerlendirmenin ardından anneye bilgilendirme toplantıları yapılması aşamasına geçilmiştir.

Birinci toplantıda öncelikle anneye kişisel bakım becerilerinin öğretimi aile eğitim programı ve programın işleyişi konusunda bilgi verilmiştir. Ardından bağımsız yaşam, günlük yaşam, öz bakım ve kişisel bakım becerilerine yönelik sunum yapılmıştır. Annneye konuyla ilgili bilgiler açık anlatım şeklinde sunulurken ipucu konularının anlatımında model olma yönteminden yararlanılmıştır.

İkinci toplantıda anneye birinci toplantıda verilen ev çalışmaları incelenmiş ardından da bireyin performansı, gereksinim duyulan beceriler ve becerilerin hangisinin daha öncelikli olduğunu belirleme, pekiştireçleri belirleme, öğretime ait çalışmaları planlama (beceriye verilen isim, çalışmanın amacı, öğretim ortamı, öğretim materyalleri, beceri analizi oluşturma), kişisel görüş noktası tekniğini açıklama konularına ilişkin açıklamalar, örnekler ve uygulamalarla ilgili sunumlar yapılmış ve örnekler verilmiştir. Aynı zamanda bu toplantıda yoklama ve öğretim oturumlarına ait örnek veri kayıt formları da anneyle birlikte hazırlanmıştır.

Üçüncü toplantıda çalışma takvimi, öğretimden önceki son hazırlıklar, öğretimde gerçekleştirilecek çalışmalara yer verilmiştir. Bu toplantıda becerinin öğretimi için gerekli olan tüm öğretimsel kavramların sunumuna yer verilmiştir. Bu çalı̧̧malar bireyin dikkatini çalışmaya çekme, beceriye ait beceri yönergesini sunma, ipucu türleri, ipucu sunma, ipucu sırası, onaylama, pekiştirme, harekete geçmeye ilişkin açıklamaları içermektedir.

Dördüncü toplantıda ise annenin çocuğuna öğreteceği örnek beceriyi (saça şekil verme) öğretme etkinliğine yer verilmiştir. Bu toplantı, uzmanın aileye ev ziyareti yapması ve uygulamanın doğal ortamda yürütülmesi, aileyle çocuk çalışırken uzmanın ihtiyaç duyulduğunda rehberlik etmesi aşamalarını da içerir. $\mathrm{Bu}$ oturumlar videoyla kayıt altına alınıp izlenerek düzeltme ve dönütlere yer verilmiştir. Ardından anne ilgili beceriyi haftanın tüm günlerinde bir oturum yoklama ve bir oturum öğretim şeklinde, kişisel görüş noktası tekniğ ine göre belirlenmiş basamakları izleyerek çocuğuyla çalışmıştır. Anne örnek beceri olan saça şekil verme becerisinde 

PROGRAMININ ETKILILİ̈̆İ

kararlı veri elde ettiğgini bildirdiğinde araştırmacı bireyin yaşadığı eve giderek örnek beceri (saça şekil verme) izleme oturumu ve "Aile Eğitimi Program Amaçlarını Değerlendirme" son test uygulaması aşamalarını gerçekleştirilmiştir. Değerlendirme süreçlerinin ardından müdahale aşamasına geçilmiştir. Müdahale aşamasınnda belirlenen becerilerin (tırnak kesme, ped kullanımı, koltuk altı tüy alma) öğretimi örnek beceri olan saça şekil verme becerisinin öğretiminde izlenen basamaklar izlenerek gerçekleştirilmiştir.

Kișisel görüș noktası tekniği kullanılarak yürütülen bu araștırmada bireyin mahremiyetinin korunması adına uygun kıyafetlerle becerilerin öğretimi gerçekleştirilmiştir. Ped kullanma becerisinde regl durumu olmadığı zamanlarda ve tayt üzerinde külot olacak şekilde kıyafetler kullanılarak; koltuk altı tüy alma becerisinde ise kolsuz bluz tercih edilerek öğretim oturumları yürütülmüsstür. Ayrıca tırnak kesme, ped kullanma ve koltuk altı tüy alma becerilerinin öğretiminin doğal süreçte yapılması uzun zaman gerektireceğinden öğretimde takma tırnak kullanma, regl olmama durumunda ped kullanma durumları söz konusu olmuştur. Öte yandan koltuk altı tüy alma becerisinde araç-gereç olarak en güvenli olabileceği düşünülerek sadece köpük kullanılmıştır. Dolayısıyla araştırmada öğretimi olumsuz etkileyebilecek her türlü olası sorunlara yönelik uyarlamalar gerçekleştirilmiştir.

\section{Başlama Düzeyi Süreci}

Araştırmada öncelikle belirlenen üç beceride başlama düzeyi verisi oturumlarına ilişkin veri toplanmıştır. Başlama düzeyi oturumlarında anne başlangıçta ortamı ve malzemeleri hazırlamıştır. Çocuğunun dikkatini çalışacakları beceriye yöneltmiştir (ör. "Bak kızım, tırnakların uzamış, biraz da şekilsiz olmuş. Tırnaklarını keselim mi, ister misin?") Çocuğunun dikkatini beceriye yöneltme davranışını sözel olarak (ör. "Harikasın, çok güzel. O halde hadi başlayalım!") pekiştirmiş̧ir. Ardından anne "Tırnak bakımını yap" şeklinde beceriye ait yönergeyi sunmuş ve beş saniye beklemiştir. Anne çocuğunu çocuk doğru, uygun tepki verirse sözel olarak (ör. "Aferin sana, çok güzel" vb.) pekiştirerek çalışmayı sürdürmesini beklemiştir. Çocuğu tepkide bulunmazsa veya yanlış tepki verirse çocuğunun çalışmaya katılımını pekiştirerek oturuma son vermiştir (ör. "Aferin sana, benimle güzel çalıştın" vb.). Oturumu bitirdikten sonra anne önceden hazırlamış olduğu veri kayıt formuna çocuğunun doğru yaptığı basamakları “+”; çocuğunun belirlenen süre içerisinde tepki vermediği ya da yanlış tepki verdiği basamaktan itibaren "-" işaretlemesini yapmıştır.

\section{Yoklama Oturumlart Süreci}

Yoklama oturumları günlük yoklama oturumları ve toplu yoklama oturumları olmak üzere iki şekilde düzenlenmiştir. Günlük yoklama oturumları ilk öğretim oturumu hariç öğretim oturumlarından hemen önce gerçekleştirilmiştir. Öğretim aşamasında katılımcıların becerileri sergileme durumları günlük yoklama oturumlarında değerlendirilmiştir. $\mathrm{Bu}$ oturumlarda başlama düzeyi evresindeki süreçle aynı süreç izlenmiştir. Toplu yoklama oturumları ise tek denekli araştırmalar içerisinde yer alan davranışlar arası yoklama evreli çoklu yoklama modeline uygun şekilde ve başlama düzeyi evresindeki süreçle aynı süreç izlenerek yürütülmüştür.

Kişisel Görüş Noktası Tekniği ile Öğretim Süreci. Anne ile yapılan toplantıların sonuncu etkinliği olan örnek becerinin (saça şekil verme becerisi) öğretiminde anne ard arda üç oturumda verilerde kararllık elde ettiği zaman öğretim uygulamalarına geçilmiştir. Bu aşamada annenin kişisel görüş tekniğini kullanarak gerçekleştirdiği öğretim sürecinde Ek D'de yer alan basamakları sergilemesi beklenmiştir. Araştırmanın öğretim materyallerini oluşturan hedef beceriye ilişkin video şu şekilde hazırlanmıştır: Katılımcı bireylerin akrabalarından olan ve genel eğitim sınıfında liseye devam eden bir kız öğrencinin öğretilecek olan becerilere ilişkin hazırlanan beceri analizlerinde yer alan basamakları görüş hizasından sergilerken video kaydı alınmıştır. Oluşturulan video kaydı özel eğitim alanında görev yapan iki özel eğitim uzmanına izlettirilmiş, gerekli değişiklikler, düzenlemeler ve eklemeler yapılıp tekrar yeni bir video kaydı hazırlanmıştır. Örnek beceri ve öğretilecek diğer becerilerin seçimi öğrencinin desteğe ihtiyaç duyduğu beceriler arasından seçilmiştir.

Kişisel görüş noktası tekniği kullanılarak yürütülen öğretim oturumları şu şekilde gerçekleştirilmiştir: a) Anne, çocuğunun dikkatini çalışmaya yöneltmek amacıyla dikkat sağlayıcı ipucunu (ör. "Sevgi, şimdi seninle tırnak bakımı becerisiyle ilgili bilgisayarda bir video izleyeceğiz. Önce videoyu izleyeceksin, ardından sen de videoda gördüğünü yapacaksın tamam mı?, Anlaştık mı?”) sözel şekilde sunmuştur. b) Çocuğunun izlediği beceriyi sergilemek istediğini sözel ya da sözel olmayan jest, mimik veya ifadelerle belirtmesinden sonra anne çocuğunun bu tepkisini sözel olarak (ör. "Süpersin, o zaman hadi başlayalım!") pekiştirmiş̧ir. c) Devamında anne çocuğuna ele alınan beceriyi sergilemesi için beceri yönergesini ("Videoyu izle!") sunarak çocuğunun tepkide bulunmasını beklemiştir. Bu aşamada anne ve çocuğu yan yana dururlar, anne tableti alır. Anne ve çocuğu öğretimi yapılacak becerinin sergilendiği video klibi izlerler. (d) Ardından çocuk beceriyi sergilemiştir. (e) Çocuğunun uygun ve doğru sergilediği beceri basamaklarında anne çocuğunu sözel pekiştireçlerle (ör. "Aferin, çok güzel!") 
pekiştirmiş̧tir. Çocuğunun hiç sergilemediği/tepkisiz kaldığı ya da yanlış sergilediği durumlarda anne hata düzeltmesi yapmıştır. Hata düzeltmesi olarak anne çocuğuna başka herhangi bir bilgi sunmamıştır. Sadece "Şimdi ne yapıyorduk?" şeklinde sözel ipucu sunmuştur. (f) Etkinliğin sonunda anne çocuğunu çalışmaya katıldığı için sözel olarak (ör. "Birlikte çok güzel çalıştık teşekkür ederim.”) ve etkinlik pekiştireçlerini (ör. "Dans edebilirsin.”) kullanarak pekiştirmiş̧tir. Anne çocuğuyla beceride ölçütü karşılanıncaya ve üç öğretim oturumu ard arda kararlı şekilde veri elde edilene değin öğretim sürecine devam etmiştir. Diğer iki becerinin öğretiminde de aynı süreç izlenmiştir.

\section{Verilerin Analizi}

\section{Aile Ĕ̆itimi Programına İlişkin Verilerin Analizi}

Annenin aile eğitimi programında yer alan konulara ilişkin bilgisini ölçmek amacıyla "Aile Eğitimi Program Amaçlarını Değerlendirme Formu" (bk. Ek A) anneye uygulanmış, sorular sözel şekilde sorulmuş ve bu süreç videoya kaydedilmiştir. Güvenirlik verilerinin toplanmasında sorumlu uzman, öğretim oturumu sona erdikten sonra videoyla kayıt altına alınan kayıtları izleyip, annenin cevaplarını forma "-/+" olarak işaretlemiştir. Bu süreçte annenin Kişisel Bakım Becerileri'nin Öğretimi El Kitabı'nda yer alan bilgilere benzer olan yanıtları doğru olarak kabul edilmiştir. Ön-test ve son-testteki doğru cevapların toplam sayısı yüzde olarak hesaplanıp veriler karşılaş̧ııılmıştır. Sütun grafiği kullanılarak veriler analiz edilmiştir. Araşıırmacının programı planladığı şekilde yürütüp yürütmediği ise kontrol listesiyle değerlendirilmiş̧tir. Kontrol listesindeki ilgili maddelerin yanına "+/-" işaretlemeleri yapılmıştır. Veriler yüzdeliğe dökülmüş ve sütun grafiği kullanılarak analiz edilmiştir.

\section{Etkililik Verilerinin Analizi}

Etkililik verileri çocuğun hedef becerilere ilişkin kişisel görüş noktası tekniğiyle öğretimine yönelik doğru ve yanlış tepkileri önceden hazırlanmış olan veri toplama kayıt formlarına kaydedilerek doğru tepki yüzdesi hesaplanmıştır. Bu veriler kişisel görüş noktası tekniği arasında yer alan öğretim uygulamaları için düzenlenen günlük yoklama oturumlarında, genelleme ve izleme oturumlarında toplanmıştır. Etkililik verileri hesaplanırken bireylerin doğru sergilediği ve yanlış sergilediği davranışlar kaydedilip doğru tepki yüzdeleri hesaplanmıştır. Veri kayıt formları aracılığıyla toplanan verilerde grafiksel analiz kullanılmış, veriler bu şekilde analiz edilmiştir. Grafik üzerinde x ekseni oturumları (yoklama, genelleme ve izleme), y ekseni ise öğretimi yapılan becerileri (tırnak bakımı, ped kullanma, koltuk altı tüy alma) ifade etmektedir. Her bir oturum evresinde bireyin doğru sergilemiş olduğu beceri basamaklarının sayısı beceri analizinde yer alan toplam basamak sayısına bölünmüştür. Böylece bireyin doğru ve uygun olarak yerine getirdiği basamakların yüzdesi elde edilmiştir. Elde edilen bu yüzdelere ilişkin değerler grafiğe işlenmiş̧tir.

\section{Güvenirlik Verilerinin Analizi}

Gözlemciler Arası Güvenirlik Verilerinin Analizi. Gözlemciler arası güvenirlik verileri analiz edilirken "Görüş birliği / Görüş birliği + Görüş ayrıllğ 1 x 100" formülü kullanılmıştır. Bu işlem tüm beceriler için tekrarlanmıştır (bk. Tablo 2).

Uygulama Güvenirliği Verilerinin Analizi. "Gözlenen uygulamacı davranışları / planlanan uygulamacı davranışı x 100" formülü kullanılarak uygulama güvenirliği hesaplanmıştır (Tekin-İftar, 2012). Tüm becerilerde süreç aynı şekilde davam etmiştir (bk. Tablo 3).

Tablo 2

Kişisel Bakım Becerileri Gözlemciler Arası Güvenirlik Verileri (Ortalama)

\begin{tabular}{lcccccc}
\hline \multicolumn{1}{c}{ Beceri } & $\begin{array}{c}\text { Başlama } \\
\text { düzeyi } \\
\text { oturumları }\end{array}$ & $\begin{array}{c}\text { Günlük } \\
\text { yoklama } \\
\text { oturumlar1 }\end{array}$ & $\begin{array}{c}\text { Toplu } \\
\text { yoklama } \\
\text { oturumlar1 }\end{array}$ & $\begin{array}{c}\text { Genelleme } \\
\text { oturumlar1 }\end{array}$ & $\begin{array}{c}\text { İzleme } \\
\text { oturumlar1 }\end{array}$ & $\begin{array}{c}\text { Güvenirlik } \\
\text { ortalamalar1 }\end{array}$ \\
\hline T1rnak bakımı & $\% 100$ & $\% 80$ & $\% 98$ & $\% 100$ & $\% 100$ & $\% 95.6$ \\
Ped kullanma & $\% 100$ & $\% 85$ & $\% 100$ & $\% 100$ & $\% 100$ & $\% 97.0$ \\
Koltuk altı tüy alımı & $\% 100$ & $\% 85$ & $\% 100$ & $\% 100$ & $\% 100$ & $\% 97.0$ \\
\hline
\end{tabular}



PROGRAMININ ETKILILİ̈̆İ

Tablo 3

Anne Tarafından Öğretilen Kişisel Bakım Becerilerinin Öğretimine ilişkin Uygulama Güvenirliği Verileri (Ortalama)

\begin{tabular}{|c|c|c|c|c|c|c|}
\hline Beceri & $\begin{array}{c}\text { Başlama düzeyi } \\
\text { oturumları }\end{array}$ & $\begin{array}{c}\text { Günlük yoklama } \\
\text { oturumları }\end{array}$ & $\begin{array}{c}\text { Toplu yoklama } \\
\text { oturumları }\end{array}$ & $\begin{array}{l}\text { Genelleme } \\
\text { oturumlar1 }\end{array}$ & $\begin{array}{c}\text { İzleme } \\
\text { oturumları }\end{array}$ & $\begin{array}{l}\text { Güvenirlik } \\
\text { ortalamaları }\end{array}$ \\
\hline Tirnak bakımı & $\% 100$ & $\% 88$ & $\% 80$ & $\% 100$ & $\% 100$ & $\% 93.6$ \\
\hline Ped kullanma & $\% 100$ & $\% 88$ & $\% 80$ & $\% 100$ & $\% 100$ & $\% 93.6$ \\
\hline Koltuk altı tüy alımı & $\% 100$ & $\% 80$ & $\% 80$ & $\% 100$ & $\% 100$ & $\% 92$ \\
\hline
\end{tabular}

\section{Sosyal Geçerlik Verilerinin Analizi}

Sosyal geçerlik verileri katılımcı anneden görüşme yoluyla elde edilen veriler aracılığıyla toplanmıştır. Annenin görüşlerinden elde edilen veriler betimsel olarak analiz edilmiştir. Sosyal geçerlik verilerine ilişkin anneden elde edilen veriler bulgular başlığında detaylı olarak açıklanmıştır.

\section{Bulgular}

$\mathrm{Bu}$ bölümde, geliştirilen $\mathrm{ZY}$ olan bireylere kişisel bakım becerilerini içeren aile eğitim programını tamamlayan annenin program doğrultusunda gerçekleştirmiş olduğu kişisel bakım becerileri öğretim çalışmalarına yer verilmiştir. Ayrıca ZY olan bireyin de kişisel bakım becerilerini öğrenmesindeki etkisine ilişkin bulgulara yer verilmiştir. Aşağıda bu süreçlere ilişkin bulgular detaylı şekilde açıklanmıştır.

\section{Aile Eğitim Programının Başarısına İlişkin Bulgular}

“Aile Eğitimi Program Amaçlarını Değerlendirme Formunun” kullanıldığı bu aşamada Anne Nazik Hanım ön-testte 20 sorunun 5'ine doğru yanıt vermiştir. Anne Nazik hanım aynı sorulardan oluşan son-testte ise 20 sorunun 18 'ine doğru yanıt vermiştir. Anne Nazik Hanım'ın aile eğitimi programını değerlendirme amacıyla hazırlanan ön-test ve son-test sorularına vermiş olduğu doğru yanıtlara ilişkin bulgular Şekil 1'de sütun grafiğinde gösterilmektedir.

\section{Şekil 1}

Anne Nazik Hanım'ın Aile Eğitimi Program Amaçlarına Yönelik Ön-test ve Son-testte Göstermiş Olduğu Doğru Cevap Yüzdeleri

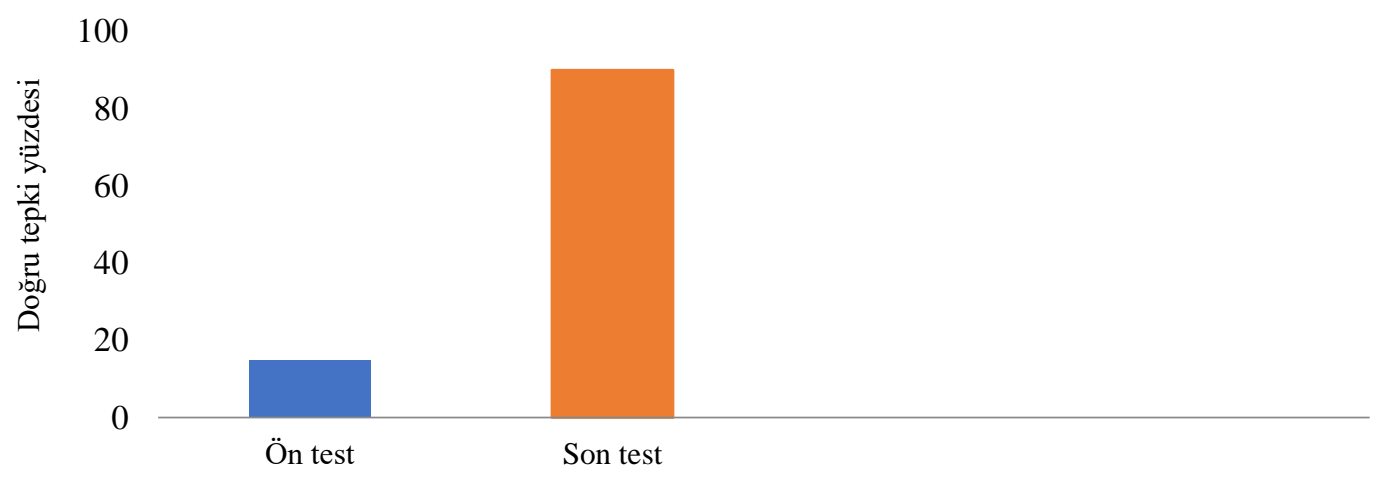

\section{Aile Eğitimi Programının Etkililiğine İlişkin Bulgular}

Anne Nazik Hanım’ın kızıyla yürüttüğü kişisel bakım becerilerinin öğretimine ilişkin bulgular Şekil 2'de yer almaktadır. Şekil 2 'de belirtildiği üzere Sevgi başlama düzeyinde ilk beceriyi ortalama \%4, ikinci beceriyi $\% 10$, üçüncü beceriyi \%5 oranında yerine getirmektedir. Öğretim sürecinde her üç beceride de hızlı artış olmuştur. Tırnak kesme becerisinde altı, ped kullanma becerisinde beş, koltuk altı tüy alma becerisinde beş oturumun sonunda öğrenci beceri basamaklarının tümünü bağımsız şekilde (\%100) yerine getirmiştir.

\section{Sosyal Geçerliğe İlişkin Bulgular}

Nazik Hanım kızı Sevgi’nin tırnak bakımı, ped kullanma, koltuk altı tüy alma ve örnek beceri olan saça şekil verme becerilerini öğrendiğini belirtmiştir. Çalışmadan sonra kızının kendisine her zaman olduğundan daha fazla güvenmeye başladığını ve bu becerileri gerçekleştirebildiği için mutlu olduğunu söylemiştir. Çocuğunun öğrendiği bu becerilerin hem çocuğuna hem de kendisine yarar sağladığını, ileride bunun faydalarını göreceklerini ifade etmiştir. Anneyle yapılan görüşmeden elde edilen bulgulara göre anne çocuğuna kişisel bakım becerilerinin 
öğretiminde aile eğitimi programının önemli olduğunu, programa yönelik çalışmaya katılmaktan memnun kaldığını, bu programa katılmalarını arkadaşlarına da önereceğini belirtmiştir.

Ayrıca anne çocuğuna kişisel bakım becerilerinin öğretiminde kullandığı kişisel görüş noktası tekniğini yararlı bulduğunu belirtmiş ve bu görüşünü "Evet çok yararlı oldu. Onunla daha çok şeyler ögretebilirim" şeklinde ifade etmiştir. Anne Nazik çocuğunun beceriyi videodan izleyip ardından o beceriyi yapmaktan çok keyif aldığını, çocuğuna farklı becerileri öğreteceği başka aile eğitim programlarına katılmayı istediğini, öğretimini yaptığı kişisel bakım becerilerinin çocuğunun günlük yaşamda bağımsız yaşam sürdürmesini kolaylaştırdığı ifadelerine de görüşlerinde yer vermiştir.

Anne Nazik, "Çalışmada sizi mutlu eden durumları söyleyebilir misiniz?” sorusuna ilişkin olarak "Tabi ki. Mesela Sevgi öz bakım becerilerini kendisi çalışmamızla halletti. Onun yanında banyosunu, ne bileyim bulaşık makinesini dizmesini, kahvaltılıklarl getir-götür yapmasını, yatak toplamasını...her şeyi büyük bir zevkle yapıyor. Çok güzel ögreniyor yani, Allah sizden razı olsun. Böyle çalışmalar olursa başka şeyler de ögrrenmek isterim." şeklinde görüşlerini belirtmiştir.

Anneye yöneltilen başka bir soru olan "Çalışmada hoşnut kalmadığınız durumları söyleyebilir misiniz?" sorusu sorulduğunda ise anne "Hoşuma gitmeyen hiçbir şey olmadı. Hoşuma giden çok şeyler oldu. Sevgi ile ilgili böyle şeylerin olması beni daha çok mutlu etti. Memnun kaldım, yani daha çok memnun kaldım. Bunlar keşke herzaman olsa." ifadeleri ile düşüncelerini aktarmıştır.

Anneye "Katıldığınız aile eğitim programında yer alsaydı daha faydalı olurdu dediğiniz uygulama var mıdır?" sorusu yöneltildiğinde anne Nazik "Daha şey...şu anda olmadı. Bi ev işleri falan var işte. En önemlilerini becerdi zaten sağolsun. Öz becerisini banyosunu, şeylerini felan. Evi toplamasını felan. Şu anda yemek şeyi kaldı, çamaşır makinası kaldı, ütü kaldı.Onları da inşallah ögreteceğiz video yöntemiyle.” şeklinde görüşlerine yer vermiştir.

Araştırmanın sosyal geçerlik bulguları incelendiğinde geliştirilen aile eğitimi programına katılan Nazik Hanım'ın programdan memnun kaldığı, kızına bu becerileri öğretebilmiş olmaktan dolayı mutlu olduğu, bu becerilerin öğrenilmesinin ailedeki tüm bireyleri ve çocuğunun eğitim aldığı kişileri de mutlu ettiği, aileye yarar sağladığı yönünde görüş bildirdiği görülmektedir. Sistematik ve tutarlı bir şekilde planlanıp uygulandığında öğretimin çok daha kolay yürütüldüğü ve bu sistematikliğin kendisinin ve kızının öğretimleri daha ciddiye almasını ve keyifle katılmasını sağladığını belirtmiştir. 


\section{Şekil 2}

Sevgi'nin Tırnak Bakımı, Ped Kullanma, Koltuk Altı Tüy Alımı Becerilerine Yönelik Başlama Düzeyi, Uygulama, Toplu Yoklama ve İzleme Oturumlarında Göstermiş Olduğu Doğru Tepki Yüzdeleri

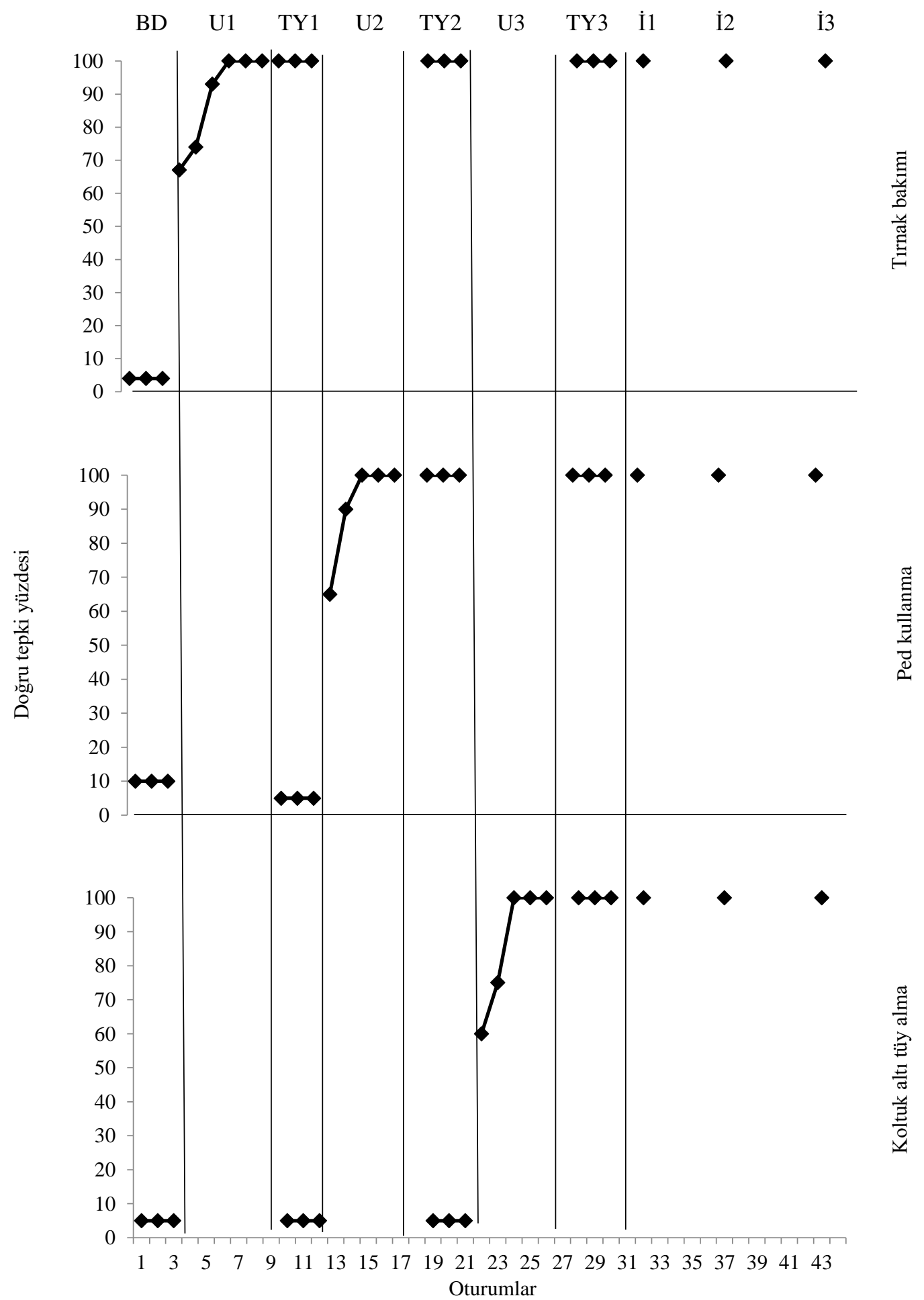

Not: BD = başlama düzeyi; $\mathrm{U}$ = uygulama; TY = toplu yoklama; $\dot{\mathrm{I}}=$ izleme (Günlük yoklama oturumları verileri kullanılmıştır). 


\section{Tartışma}

Araştırmanın sonuçlarına bakıldığında toplantılar, ev ziyaretleriyle kişisel görüş noktası tekniği ile kişisel bakım becerilerinin öğretimini içeren programı tamamlayan anne Nazik’in program doğrultusunda çocuğuyla gerçekleştirdiği öğretim çalışmalarının çocuğunun kişisel bakım becerilerini edinmesinde etkili olduğu görülmektedir. Bununla birlikte Sevgi'nin kişisel bakım becerilerini çalışma tamamlandıktan bir, iki, üç hafta sonra da devam ettirdiği görülmüştür. Ayrıca anne, kişisel görüş noktası tekniğiyle öğretim sunabilme becerisini güvenirliği yüksek şekilde ve bağımsız olarak sergileyebilmiştir.

Alanyazında kişisel bakım becerileriyle ilgili yürütülmüş çalışmalara bakıldığında Cavkaytar (1998) öz bakım becerilerinden tırnak kesme becerisini; Özen ve diğerleri (2002) diş firçalama becerisini; Özcan (2004) tuvalet becerisini; Sönmez (2008) tuvalet kontrolü becerisini; Ersoy (2005) ped değiştirme becerisini; Çakmak (2011) öz bakım becerilerini; Öncül ve Yücesoy-Özkan (2010) hijyenik ped değiştirme ve diş firçalama becerilerini öğretmişlerdir. Yürütülen bu çalışmalarda kullanılan yöntemlerin etkili olduğu, ZY olan bireylerin kendilerine öğretilen becerileri edindikleri, farklı ortam, durum ve araç-gereçlere genelledikleri ve edindikleri becerileri korudukları görülmektedir. Gerçekleştirilen bu araştırmanın bulguları alanyazındaki çalışmaların bulgularıyla tutarlılık göstermektedir.

Videoyla model olma becerilerin doğal ortamlarda kolaylıkla öğretiminin yapılabilmesine olanak sağlayan bir yöntemdir (Charlop-Christy vd., 2000; Corbett, 2003; Thelen vd., 1979). Bu yöntem, alış-veriş yapma, tıraş olma, ped kullanma ve tırnak kesme vb. her durumda gerçek bir ortam ve model kullanılarak çalışma olanağının olmadığı anlarda başvurulması gereken bir yöntemdir. Özel gereksinimi olan bireyler için planlanan ya da öğretilmesi istenilen beceri ve davranışları anlatan video görüntüleri oluşturularak kullanılan bu yöntem farklı yetersizlikte olan bireylere de uyarlanabilmektedir. Televizyon, telefon, bilgisayar, kamera gibi teknolojik araçları temin etmenin zor olması, öğretim görüntülerini hazırlama aşamasında video kamerayı sadece beceriyi çekecek şekilde (kişisel görüş açısından) ayarlamanın zor olması video görüntülerini hazırlamanın uzun zaman alması ise yöntemin sınırlılıklarındandır. Yürütülen bu araştırmada da koltuk altı tüy alımı becerilerinde video model olan kişinin normalde kullandığı malzemelerden farklı malzeme kullanmak durumunda kalması, vidodaki eksiklikleri tamamlamak için bir kaç kez çekim yapılması gerektiğinde becerinin önkoşulu için zaman gerekmesi, ped kullanma becerisinde gerçekten regl olma durumunda becerinin çalışılamaması, ped kullanma ve koltuk altı tüy alma becerisinde mahremiyeti korumak adına video görüntülerinde model olan kişinin kıyafetinde uyarlamalar yapılması durumunda kalınması, gerçek bir regl durumu söz konusu olmadığı için temiz pedi takma ve kirli pedi çıkarma basamaklarında önceliği belirlemenin zor olması gibi güçlükler yaşanmıştır. Tüm bu sınırlılıklara rağmen hazırlanan görüntülerin tekrar tekrar izlenebilmesi ve uygulamacıya ek bir yük getirmemesi yöntemin sıklıkla kullanılmasını mümkün kılmaktadır (Mechling, 2005).

$\mathrm{Bu}$ araştırmada video model türlerinden kişisel görüş noktası tekniğinin tercih edilmesinin sebebi katılımcı bireyin taklit becerilerinin çok gelişmiş olması, video izlemeden büyük keyif alması, izlediğini yapma ve verilen rolü sergilemede başarılı olmasıdır. Bu durum öğrenmeyi olumlu etkilemiştir. Çalışmanın katılımcı öğrencisinin hafif düzeyde zihinsel yetersizlikten etkilenmiş olması, çalışmaya katılımda istekli olması (kendisine neden söz konusu becerilerin öğretildiği açıklandığında), çalışılacak becerilerin öğrencinin yaşantısında önemli düzeyde gereksinim duyduğu beceriler olması da beceri öğretimini kolaylaştıran ve etkili kılan durumlar olarak düşünülebilir. Çalışılan beceriler zincirleme beceriler olduğu için hata düzeltmesinin gerçekleştirilmesi bireyin ard arda aynı beceri basamağını yanlış yapmasını engellemiştir. Bu durum bireyin doğru tepki vermesine yardımcı olmuştur.

Kişisel bakım becerilerinin öğretiminde alanyazında genellikle maket üzerinden öğretim ya da oyuncak bebekle öğretim tercih edildiği görülmektedir (Epps vd., 1990; Ersoy, 2005; Richman vd., 1986). Ersoy (2005), çalışmasında menstürasyon dönemine girmiş ZY olan kız öğrencilere ped değiştirme becerisini öğretmede davranış öncesi ipucu ve sınamayla öğretimin etkililiğini değerlendirmeyi amaçlamıştır. Araştırmacı çalışmasında maket kullanmıştır. Bulgulara bakıldığında davranış öncesi ipucu ve sınamayla öğretim yönteminin maket üzerinde ped değiştirme becerisinin öğretilmesindeki etkililiğinin yüksek olduğu görülmüştür. Bu araştırmada alanyazındaki araştırmalardan farklı olarak becerinin öğretimi bireyin bizzat kendi vücudu üzerinde gerçekleştirilmiştir. Maket üzerinde öğretimin sonuçlarıyla benzer sonuçlar elde edilen bu araştırmada da birey beceriyi kısa sürede ve etkili şekilde gerçekleştirmiştir. Bu yönüyle araştırma alanyazını desteklemektedir.

Araştırmada bireyin mahremiyetinin korunması adına uygun kıyafetlerle becerilerin öğretimi gerçekleştirilmiştir. Ped kullanma becerisinde regl durumu olmadığı zamanlarda ve tayt üzerinde külot olacak şekilde kıyafet; koltuk altı tüy alma becerisinde ise kolsuz bluz tercih edilmiştir. Kişisel görüş noktası tekniğinde 
video görselinde sadece becerinin yer alması ve bu videoda kişinin kendi onayı alınarak katılımcının akrabalarından birinin beceriyi sergilemesi için model olmaya gönüllü olması olası etik dışı durumları önlemiştir. Ayrıca tırnak kesme, ped kullanma ve koltuk altı tüy alma becerilerinin öğretimini yapabilmek uzun zaman gerektiren bir beceri olduğu için bu becerilerin öğretiminde takma tırnak kullanma, regl olmama durumunda ped kullanma şeklinde süreç izlenmiştir. Öte yandan koltuk altı tüy alma becerisinde araç-gereç olarak en güvenli olabileceği düşünülerek sadece köpük kullanılmıştır. Dolayısıyla araştırmada öğretimi olumsuz etkileyebilecek her türlü olası sıkıntılara yönelik uyarlamalar yapılmıştır.

Bu bulgular ışığında ZY olan bireylere kişisel bakım becerilerinin öğretimine yönelik oluşturulan aile eğitimi programını tamamlamış olan annenin program süresince yerine getirdiği becerilere yönelik öğretim çalışmalarının, ZY olan çocuğunun kişisel bakım becerilerini öğrenmesinde etkili olduğu söylenebilir. Etkili sonuçlar elde edilen bu araştırmanın bulgularından hareketle uygulamaya ve ileri araştırmalara ilişkin birtakım önerilere yer verilmiştir. Aile katılımını sağlayacak etkililiği kanıtlanmış programların yaygınlaş̧ırılabileceği, aile eğitim programlarının öğretmenler tarafindan ailelere tanıtılması ve uygulamaya geçmeleri konusunda ailelerin cesaretlendirilebileceği, ailelerin özel eğitim öğretim yöntemlerindeki temel süreçler (yönerge verme, pekiçtireç kullanma, beceri analizi hazırlama, kayıt tutma vs.) konusunda bilgilendirilebileceği; öğretmenlerin okul ortamında kazandırmada etik sorunlar yaşayabileceği becerilerin öğretiminde bu tür video model seçeneklerinin kullanılabileceği noktasında uygulamaya yönelik önerilerde bulunulabilir. Geliştirilen aile eğitim programının etkililiği ile ilgili çalışmalara aileden farklı kişilerin (baba, kardeş, bakıcı, akraba) dahil edilebileceği, çalışmada yer alan yetersizlik türünden farklı yetersizliği olan ve tipik gelişim gösteren çocuğa sahip ailelerle tekrarlanabileceği, farklı bağımsız yaşam becerileri için geliştirilen aile eğitim programına benzer programlar oluşturulup uygulanabileceği, okuma-yazma becerilerine sahip olmayan ebeveynler için de uyarlanarak kullanılabileceğine ilişkin öneriler araştırmalara yönelik olarak verilebilir.

\section{Yazarların Katkı Düzeyleri}

Araştırma konusunun belirlenmesi, literatür taraması ve alanyazın yazımı, araştırmanın uygulama sürecinin planlanması, araştırma verilerinin analiz edilerek sonuçların tartışılması, araştırmanın raporlaştırılması sürecinde ikinci yazar ilk yazara rehberlik etmiştir. Araştırmanın deney sürecini ise ilk yazar yürütmüştür. Her iki yazarın da araştırmaya katkı oranları $\% 50$ 'dir. 


\section{Kaynaklar}

Acar, Ç. (2015). Otizmli çocuklara sosyal becerilerin ögretiminde anneler tarafindan hazırlanarak sunulan sosyal öykü ve video modelle ögretim uygulamalarının karşılaştırılması [Comparison of teaching practices by social story and video model prepared and presented by mothers in teaching social skills to children with autism] (Tez Numarası: 394742) [Doktora tezi, Bolu Abant İzzet Baysal Üniversitesi]. Yükseköğretim Kurulu Ulusal Tez Merkezi.

Aydın, O., \& Cavkaytar, A. (2019). Otizm spektrum bozukluğu olan bir çocuğa temel matematik becerilerinin öğretiminde baba eğitim programının etkililiği [Effectiveness of the father education program in teaching basic math skills to a child with autism spectrum disorder]. Ankara Üniversitesi Eğitim Bilimleri Fakültesi Özel Ĕgitim Dergisi, 21(1), 71-94. https://doi.org/10.21565/ozelegitimdergisi.523342

Aykut, Ç., \& Varol, N. (2010). Zihinsel yetersizlikten etkilenmiş öğrencilere günlük yaşam becerilerinin kazandırılmasında sabit bekleme süreli ve ipucunun sistematik olarak geri çekilmesi işlem süreci ile yapılan öğretimin etkililik ve verimliliklerinin karşılaştırılması [Comparison of the effectiveness and efficiency of the teaching with the fixed waiting period and the systematic withdrawal of the clue in the teaching of daily life skills to students affected by intellectual disability]. Türk Eğitim Bilimleri Dergisi, 8(1), 227-261. https://dergipark.org.tr/en/download/article-file/256266

Batu, S. (2008). Gelişimsel yetersizliği olan öğrencilere bakımlarını yapan kişiler aracılığıyla eşzamanlı ipucu kullanılarak ev becerilerinin öğretimi [Teaching home skills to students with developmental disabilities by using simultaneous hints through caregivers]. Education and Training in Developmental Disabilities, 43(4), 541-555. https://www.jstor.org/stable/23879682

Batu, S. E., Bozkurt, F., \& Öncül, N. (2014). Effectiveness of mother delivered simultaneous prompting taught by visual support on teaching chained skills to their children with autism. Education and Science, 39(174), 91-104. https://doi.org/10.15390/EB.2014.2367

Boyraz, G. (2015). Aile e ğitim programının annelerin ayrımlı pekiştirme kullanarak çocuklarına kural kazandırma becerisini edinmelerine etkisi [The effect of family education program on mothers' ability to gain rules by using differential reinforcement] (Tez Numaras1: 388186) [Yüksek lisans tezi, Gazi Üniversitesi]. Yükseköğretim Kurulu Ulusal Tez Merkezi.

Brolin, D. E. (1997). Life centered career education: A competency based approach (5th ed.). The Council for Expectional Children.

Cavkaytar, A. (1998). Zihin engellilere özbakım ve ev içi becerilerinin ögrretiminde bir aile eğitimi programının etkiliği [The effectiveness of a family education program in the teaching of mentally handicapped selfcare and home skills] (Tez Numarası: 73470) [Doktora tezi, Anadolu Üniversitesi]. Yükseköğretim Kurulu Ulusal Tez Merkezi.

Cavkaytar, A. (2000). Zihin engellilerin eğitim amaçları [Educational objectives of the mentally retarded]. Anadolu Üniversitesi Ĕ̈itim Fakültesi Dergisi, 10(1), 115-121.

Cavkaytar, A., \& Pollard, E. (2009). Effectiveness of parent and therapist collaboration program (PTCP) for teaching self-care and domestic skills to individual with autism. Education and Training in Mental Retardation and Developmental $\quad$ Disabilities, $381-394$. https://8132462625711418be6483c2d0db774bf632dd5b.vetisonline.com/stable/24233482?seq=2\#metad ata_info_tab_contents

Charlop-Christy, M. H., Le, L., \& Freeman, K. A. (2000). A comparison of video modeling with in vivo modeling for teaching children with autism. Journal of Autism and Developmental Disorders, 30(6), 537-552. https://doi.org/10.1023/A:1005635326276

Corbett, B. A. (2003). Video modeling: A window into the world of autism. The Behavior Analyst Today, 4(3), 367-377. https://doi.org/10.1037/h0100025

Çakmak, S. (2011). Görme engelli çocuklara özbakım becerileri kazandırmada video ile model olunarak sunulan aile eğitim programinın etkililiğ [The effectiveness of the family education program offered as a model by video in providing self-care skills to visually impaired children] (Tez Numaras1: 290693) [Doktora tezi, Gazi Üniversitesi]. Yükseköğretim Kurulu Ulusal Tez Merkezi. 

PROGRAMININ ETKILILİ̈̆İ

Çankaya, S. (2013). Zihin engellilere özbakım ve ev içi becerilerinin öğretiminde ailelere yönelik beceri öğretimi yazllımının gelişstirilmesi ve değerlendirilmesi [Development and evaluation of skill teaching software for parents of individuals with intellectual disability to teach self care and domestic skills] (Tez Numaras1: 342584) [Doktora tezi, Anadolu Üniversitesi]. Yükseköğretim Kurulu Ulusal Tez Merkezi.

Doğan, S. (2010). Zihin engelli çocuğu olan ailelerin eğitim ihtiyaçlarının belirlenmesi [Determining the educational needs of families with mentally retarded children] (Tez Numaras1: 264125) [Yüksek lisans tezi, Marmara Üniversitesi]. Yükseköğretim Kurulu Ulusal Tez Merkezi.

Douglas, S. N., Kammes, R., \& Nordquist, E. (2017). Online communication training for parents of children with autism spectrum disorder. Communication Disorders Quarterly, 39(3), 415-425. https://doi.org/10.1177\%2F1525740117727491

Epps, S., Stern, R. J., \& Horner, R. H. (1990). Comparison of simulation training on self and using a doll for teaching generalized menstrual care to women with severe mental retardation. Research in Developmental Disabilities, 11(1), 37-66. https://doi.org/10.1016/0891-4222(90)90004

Ersoy, G. (2005). Zihin özürlü ergen klz öğrencilere market üzerinde menstüral bakım becerisinin kazandırlmasinda davranış öncesi ipucu ve sinamayla ögretimin etkileri [The effects of teaching with pre-behavioral clue and testing on gaining menstrual-minded adolescent female students with menstrual care skills on the market] (Tez Numarası: 187956) [Yüksek lisans tezi, Anadolu Üniversitesi]. Yükseköğretim Kurulu Ulusal Tez Merkezi.

Gökçe, S. (2017). Otizm spektrum bozukluğu olan çocuğa sahip ailelerin katıldıkları aile eğitimi programı sonrasindaki yaşam döngüsüne ilişsin görüşleri [Views of families with children with autism spectrum disorders about the life cycle after the family education program they participated in] (Tez Numaras1: 463473) [Yüksek lisans tezi, Anadolu Üniversitesi]. Yükseköğretim Kurulu Ulusal Tez Merkezi.

Hagiwara, T., \& Smith-Myles, B. (1999). A multimedia social story intervention: Teaching skills to children with autism. Focus on Autism and Other Developmental Disabilities, 14(2), 82-95. https://doi.org/10.1177/108835769901400203

Karaaslan, Ö. (2010). Etkileşime dayalı erken eğitim programının (EDEP) gelişimsel yetersizliğe sahip çocuklar ve anneler üzerindeki etkililiği [The effectiveness of the interactive early education program (EDEP) on children and mothers with developmental disabilities] (Tez Numaras1: 265733) [Doktora tezi, Anadolu Üniversitesi]. Yükseköğretim Kurulu Ulusal Tez Merkezi.

Mechling, L. C. (2005). The effect of instructor-created video programs to teach students with disabilities: A literature review. Journal of Special Education Technology, 20(2), 25-37. https://doi.org/10.1177/016264340502000203

Okyar, S., \& Çakmak, S. (2019). Yetişkin görme engelli bireylere günlük yaşam becerilerinin kazandırılmasında eşzamanlı ipucuyla öğretimin etkililiği [The effectiveness of teaching with simultaneous prompting in providing daily life skills to adults with visual impairment]. Ankara Üniversitesi Eğitim Bilimleri Fakültesi Özel Eğitim Dergisi, 20(2), 209-236. https://doi.org/10.21565/ozelegitimdergisi.403738

Orum-Çattık, E., \& Ergenekon, Y. (2019). Otizm spektrum bozukluğu olan bireylere bağımsız yaşam becerilerinin öğretildiği araştırmaların incelenmesi [Examination of researches that teach independent life skills to individuals with autism spectrum disorders]. Anadolu Journal of Educational Sciences International, 9(2), 572-607. https://doi.org/10.18039/ajesi.577594

Öncül, N., \& Yücesoy-Özkan, Ş. (2010). Orta ve ileri düzeyde yetersizliği olan yetişkinlere videoyla model olma kullanılarak günlük yaşam becerilerinin öğretilmesi [Teaching daily life skills using video modeling to adults with moderate and advanced disabilities]. Anadolu Üniversitesi Sosyal Bilimler Dergisi, 10(3), 143-156. https://kutuphane.dogus.edu.tr/mvt/pdf.php

Özcan, N. (2004). Zihin özürlü çocuklara tuvalet becerisi öğretimine yönelik aile eğitimi programının etkililiğgi [The effectiveness of the family education program for teaching toilet skills for mentally handicapped children] (Tez Numarası: 143846) [Doktora tezi, Anadolu Üniversitesi]. Yükseköğretim Kurulu Ulusal Tez Merkezi. 
Özel Eğitim Hizmetleri Yönetmeliği [Special Education Services Regulation]. (2018). T.C. Resmi Gazete, (30471), 07 Temmuz 2018, 22-77.

Özen, A., Acar, Ç., Tavlar, Ö., \& Çetin, Ö. (2002) Öz bakım becerilerinin öğretiminde ipucunun giderek azaltılmasıyla öğretim yönteminin etkililiği [The effectiveness of the teaching method by gradually reducing the hint in the teaching of self-care skills]. Anadolu Üniversitesi Sosyal Bilimler Dergisi, 2, 169186. https://core.ac.uk/download/pdf/7169801.pdf

Özkubat, U., \& Töret, G. (2014). Zihinsel yetersizliği olan çocuklara gündüz tuvalet kontrolü becerisi öğretiminde anneleri tarafından sunulan geleneksel gündüz tuvalet kontrolü öğretiminin etkililiği [The effectiveness of traditional day toilet control teaching offered by their mothers in teaching day toilet control skills to children with mental disabilities]. Pamukkale Üniversitesi Eğitim Fakültesi Dergisi, 35(35), 61-84. https://doi.org/10.9779/PUJE644

Patterson, S. Y., Smith, V., \& Mirenda, P. (2012). A systematic review of training programs for parents of children with autism spectrum disorders: Single subject contributions. Autism, 16(5), 498-522. https://doi.org/10.1177\%2F1362361311413398

Purpura, D. J., Baroody, A. J., \& Lonigan, C. J. (2013). The transition from informal to formal mathematical knowledge: Mediation by numeral knowledge. Journal of Educational Psychology, 105(2), 453-464. https://doi.org/10.1037/a0031753

Richman, G. S., Ponticas, Y., Page, T. J., \& Epps, S. (1986). Simulation procedures for teaching independent menstrual care to mentally retarded persons. Applied Research in Mental Retardation, 7(1), 21-35. https://doi.org/10.1016/0270-3092(86)90015-9

Shanley, L., Clarke, B., Doabler, C. T., Kurtz-Nelson, E., \& Fien, H. (2017). Early number skills gains and mathematics achievement: Intervening to establish successful early mathematics trajectories. The Journal of Special Education, 51(3), 177-188. https://doi.org/10.1177\%2F0022466917720455

Shipley-Benamou, R., Lutzker, J. R., \& Taubman, M. (2002). Teaching dailly living skills to children with autism through instructional video modeling. Journal of Possitive Behavior Interventions, 4(3), 165-188. https://doi.org/10.1177/10983007020040030501

Skwarchuk, S. L., Sowinski, C., \& LeFevre, J. A. (2014). Formal and informal home learning activities in relation to children's early numeracy and literacy skills: The development of a home numeracy model. Journal of Experimental Child Psychology, 121, 63-84. https://doi.org/10.1016/j.jecp.2013.11.006

Sönmez, N. (2008). Eve dayalı gündüz tuvalet kontrolü aile eğitimi programı'nın annelerin kuruluk kaydı tutma ile gündüz tuvalet kontrolü kazandırma becerisini ve çocukların gündüz tuvalet kontrolünü kazanmasindaki etkisi [The effect of home based day toilet control family education program on the ability of mothers to keep a record of dryness and gaining daytime toilet control and to gain children daytime toilet control] (Tez Numarası: 218456) [Doktora tezi, Gazi Üniversitesi]. Yükseköğretim Kurulu Ulusal Tez Merkezi.

Sönmez, N., \& Aykut, Ç. (2011). Using mother delivered simultaneous prompting for teaching independent toileting skills to a child with developmental disability. Journal of Human Sciences, 8(1), 1151-1171. https://j-humansciences.com/ojs/index.php/IJHS/article/view/1302

Sönmez, N., \& Varol, N. (2009). Annelere eve dayalı gündüz tuvalet kontrolü öğretme becerilerinin kazandırılması [Acquiring teaching skills to mothers about daytime toilet training]. Eğitim Bilimleri ve Uygulama, 8(16), 159-178.

https://www.researchgate.net/publication/338630321_Annelere_eve dayalı_gunduz tuvalet_kontrolu_o gretme becerılerının kazandırılması

Tavil, Y. Z. (2005). Davranış denetimi aile eğitim programının annelerin davranışsal işlem süreçlerini kazanmalarina etkisi [The effect of behavioral control family education program on mothers gaining behavioral process processes] (Tez Numarası: 159552) [Doktora tezi, Gazi Üniversitesi]. Yükseköğretim Kurulu Ulusal Tez Merkezi. 

PROGRAMININ ETKILILİĞİ

Tekin-Ifftar, E. (2008). Parent-delivered community based instruction with simultaneous prompting for teaching community skills to children with developmental disabilities. Education and Training in Developmental Disabilities, 43(2), 249-265. https://www.jstor.org/stable/23879933

Tekin-İftar, E. (2012). Çoklu yoklama modelleri. E. Tekin-İftar (Ed.), Eğitim ve davranış bilimlerinde tek-denekli araşttrmalar [Single-subject research in educational and behavioral sciences] içinde (ss. 217-255). Türk Psikologlar Derneği Yayınları.

Thelen, M. H., Fry, R. A., Fehrenbach, P. A., \& Frautschi, N. M. (1979). Therapeutic videotape and film modeling: A review. Psychological Bulletin, 86(4), 701-720. https://psycnet.apa.org/doi/10.1037/00332909.86.4.701

Ulugöl, F., \& Cavkaytar, A. (2020). Zihin yetersizliği olan bireylere ev içi becerilerinin öğretiminde aile eğitimi programının etkililiği [The effectiveness of parent training program in teaching domestic skills to individuals with intellectual disability]. Anadolu Journal of Educational Sciences International, 10(2), 930-957. https://doi.org/10.18039/ajesi.760299

Ünal, M., Ece, A. S., \& Yıkmış, A. (2016). Zihin engelli çocuklara öz bakım becerilerinin şarkı yoluyla ögretilmesi. [Teaching self-care skills to mentally retarded children with the song] Mehmet Akif Ersoy Üniversitesi, Sosyal Bilimler Enstitüsü Dergisi, 8(17), 139-153. https://doi.org/45268/567020

Varol, N. (2004). Öz bakım becerilerinin öğretimi [Teaching self-care skills] (2. bask1). Kök Yayıncılık.

Wandry, D., Wehmeyer, M. L., \& Glor-Scheib, S. (2013). Life centered education: The teacher's guide. Council for Exceptional Children.

Welterlin, A., Turner-Brown, L. M., Harris, S., Mesibov, G., \& Delmolino, L. (2012). Home teaching program for toddlers with autism. Journal of Autism Developmental Disorder, 42(6), 1827-1835. https://doi.org/10.1007/s10803-011-1419-2 
Ekler

Ek A

Aile Eğitim Program Amaçlarını Değerlendirme Ölçü Aracı (Ön test-Son test)

\begin{tabular}{l}
\hline \multicolumn{1}{c}{ Sorular } \\
\hline 1. Bağımsız yaşam becerileri nelerdir? \\
2. Günlük yaşam becerileri nelerdir? \\
3. Öz bakım becerileri nelerdir? \\
4. Kişisel bakım becerileri nelerdir? \\
5. Çocuğunuzun genel performansı nedir? \\
6. Çocuğun ihtiyacı olan becerileri nasıl belirleriz? \\
7. Pekiştireç/ödül nedir? \\
8. Ne tür pekiştireçleri vardır? Bunlara örnek verir misiniz? \\
9. Pekiştireçler nasıl belirlenir? \\
10. Pekiştirme kullanımında nelere dikkat edilmelidir? \\
11. Öğretim yaparken pekiştireçleri nasıl kullanılır? \\
12. Beceri analizi ne demektir? \\
13. Çocuğunuzla öğretime başlamadan önce çocuğunuzun dikkatini nasıl çekersiniz? \\
14. Öğretimden önce ne gibi hazırlıklar yapılmalıdır? \\
15. Beceri yönergesi ne demektir? \\
16. İpucu ne demektir? \\
17. İpucu türleri nelerdir? \\
18. İpucu kullanırken sıralama nasıl olmalıdır? \\
19. Bir öğretim sürecinin nasıl gerçekleştiğini anlatır mısınız? \\
20. Öğretim sürecinde değerlendirme nasıl yapılır? Anlatır mısınız?
\end{tabular}




\section{Ek B}

Aile Eğitim Programı Uygulama Kontrol Listesi

Beceriler

1- Oturumlarda aileyle selamlaşmalar gerçekleştirildi mi?

2- Aile gereksinimleri belirlendi mi?

3- Katılımcıya hazırlanan kişisel bakım becerilerinin öğretiminin içeriği anlatıldı mı?

4- Katılımcı onayı ve gerekli izinler alındı mı?

5- Aileye etik kurallar açıklandı mı?

6- Aile görüşmeleri için randevular alındı mı?

7- Aile toplantıları için yer, zaman belirlenip materyaller hazırlandı mı?

8- Kişisel bakım becerileri el kitabı hazırlandı mı?

9- Belirlenen zamanlarda toplantılar yapıldı mı?

10- İçerikte yer alan tüm konularda bilgilendirme yapıldı mı?

11-Tüm konularla ilişkili örnekler verildi mi?

12- Toplantı kapsamında anneye ödevler verildi mi?

13- Ödevlerde anlaşılmayan kısımlar açıklandı mı?

14- Toplantı esnasında anlaşılmayan yerler açıklandı mı?

15- Ev ziyaretleri gerçekleştirildi mi?

16-Süreçte aileyle telefonla görüşmeler yapıldı mı?

17- Aile ve çocuk katılımı pekiştirildi mi?

18- Uygulama sürecinde annenin verilen ödevleri/görevleri yapması kontrol edildi mi?

19- Annenin öğretim uygulamasına dair kayıt tutuldu mu?

20- Tüm süreç kayıt altına alındı mı?

21- Bir önceki görüşme konuları tekrar edildi mi?

22- Sonraki görüşmenin içeriğinden bahsedildi mi?

23- Katılımcıya sormak istediği/anlaşılmayan bir yerin olup olmadığı soruldu mu?

24- Katılımcının öğretim oturumlarını gerçekleştirebilme durumu değerlendirildi mi?

25- Aileye katılımdan dolayı teşekkür edildi mi? 
Ek C

Yoklama Oturumları Veri Kayit Formu

\begin{tabular}{|c|c|c|c|c|c|c|c|}
\hline $\begin{array}{ll}\text { Becerinin Adı : Saça Şekil Verme (Örnek beceri) } \\
\text { Amaç } & \text { : Bağımsız olarak saçına şekil verir. } \\
\text { Malzemeler } & \text { : Tarak, saç şekillendirici, toka, su, sabun, havlu } \\
\text { Ortam } & \text { : Banyo }\end{array}$ & \multicolumn{7}{|c|}{ OTURUMLAR } \\
\hline Beceri Basamakları & 1 & 2 & 3 & 4 & 5 & 6 & 7 \\
\hline 1. Banyoya gider ve aynanın karşısına geçer. & & & & & & & \\
\hline 2. Saç şekillendiriciyi alır. & & & & & & & \\
\hline 3. Saç şekillendiricinin kapağını açarak şekillendiriciden avucuna döker. & & & & & & & \\
\hline 4. Saç şekillendiriciyi lavaboya bırakır. & & & & & & & \\
\hline 5. Kafasını öne/yana eğer. & & & & & & & \\
\hline 6. Avuç içerisindeki saç şekillendiriciyi saçlarına sürer. & & & & & & & \\
\hline 7. Saçını arkaya atar. & & & & & & & \\
\hline 8. Tarağı alır. & & & & & & & \\
\hline 9. Saçlarının uç kısımlarına tarağı geçirerek saçlarının uçlarını açar. & & & & & & & \\
\hline 10. Saçlarının tüm bölgesini tarağı yukarıdan aşağıya doğru hareket ettirerek tarar. & & & & & & & \\
\hline 11. İki eliyle saçlarını tutarak bir araya getir. & & & & & & & \\
\hline 12. Topladığ 1 saçı tek eli ile tutar. & & & & & & & \\
\hline 13. Tokayı alır ve saçından birkaç kez geçirir. & & & & & & & \\
\hline $\begin{array}{l}\text { 14. Topladığı saçı ortadan ikiye ayırır ve ayırdığı saçı her iki tarafa çekerek tokayı } \\
\text { sağlamlaştırır. }\end{array}$ & & & & & & & \\
\hline 15. Saç şekillendiriciyi alır ve şekillendiriciden avucuna döker. & & & & & & & \\
\hline 16. Saç şekillendiricisini yerine koyar. & & & & & & & \\
\hline 17. Saçının ön kısımları ve topladığı kısmına saç şekillendiricisini sürer. & & & & & & & \\
\hline 18. Ellerini yıkar. & & & & & & & \\
\hline 19. Ellerini kurular. & & & & & & & \\
\hline Doğru Tepki Sayısi/Yüzdesi & & & & & & & \\
\hline Yanlış Tepki Sayıs1/Yüzdesi & & & & & & & \\
\hline Tepkide Bulunmama Sayısı/Yüzdesi & & & & & & & \\
\hline
\end{tabular}




\section{Yoklama Oturumları Veri Kayıt Formu (Devam)}

\begin{tabular}{|c|c|c|c|c|c|c|c|}
\hline $\begin{array}{ll}\text { Becerinin Adı : } & \text { Tirnak kesme } \\
\text { Amaç } & \text { : Bağımsız olarak tırnak bakımını yapar. } \\
\text { Malzemeler } & \text { : Tirnak makası, törpü, jel, kağıt havlu, su, sabun, havlu } \\
\text { Ortam } & \text { : Yatak odası }\end{array}$ & & & UR & UN & IL & & \\
\hline Beceri Basamakları & 1 & 2 & 3 & 4 & 5 & 6 & 7 \\
\hline 1. Koltuğa kağıt havlu serer. & & & & & & & \\
\hline 2. Tırnaklarını jel ile ıslatır. & & & & & & & \\
\hline 3. Tirnak makasinı alır. & & & & & & & \\
\hline 4. Sağ elinin baş ve işaret parmağını kullanarak tırnak makasını tutar. & & & & & & & \\
\hline 5. Tırnak makasını sol elinin küçük parmak tırnağına yerleştirir. & & & & & & & \\
\hline 6. Makası bastırarak tırnağını keser. Diğer tırnaklarını da aynı şekilde keser. & & & & & & & \\
\hline 7. Sol elinin baş ve işaret parmağını kullanarak tırnak makasını tutar. & & & & & & & \\
\hline 8. Tırnak makasını sağ elinin küçük parmak tırnağına yerleştirir. & & & & & & & \\
\hline 9. Makası bastırarak tırnağını keser. Diğer tırnaklarını da aynı şekilde keser. & & & & & & & \\
\hline 10. Makası yerine koyar. & & & & & & & \\
\hline 11. Törpüyü alır. & & & & & & & \\
\hline 12. Sağ elinin baş ve işaret parmağını kullanarak törpüyü tutar. & & & & & & & \\
\hline $\begin{array}{l}\text { 13. Törpüyü sol elinin küçük parmağındaki tırnağa değdirerek sağa-sola hareket } \\
\text { ettirir. }\end{array}$ & & & & & & & \\
\hline 14. Diğer parmakların tırnaklarını da aynı şekilde törpüler. & & & & & & & \\
\hline 15. Sol elinin baş ve işaret parmağını kullanarak törpüyü tutar. & & & & & & & \\
\hline $\begin{array}{l}\text { 16. Törpüyü să̆ elinin küçük parmağındaki tırnağa değdirerek sağa-sola hareket } \\
\text { ettirir. }\end{array}$ & & & & & & & \\
\hline 17. Diğer parmakların tırnaklarını da aynı şekilde törpüler. & & & & & & & \\
\hline 18. Jeli yerine koyar. & & & & & & & \\
\hline 19. Kağıt havluyu toplayarak çöpe atar. & & & & & & & \\
\hline 20. Elini y1kar. & & & & & & & \\
\hline 21. Elini kurular. & & & & & & & \\
\hline 22. Kremi alır ve ellerine sürer. & & & & & & & \\
\hline 23. Kremi yerine koyar. & & & & & & & \\
\hline Doğru Tepki Sayısı/Yüzdesi & & & & & & & \\
\hline Yanlış Tepki Sayısi/Yüzdesi & & & & & & & \\
\hline Tepkide Bulunmama Sayısı/Yüzdesi & & & & & & & \\
\hline
\end{tabular}




\section{Yoklama Oturumları Veri Kayıt Formu (Devam)}

\begin{tabular}{|c|c|c|c|c|c|c|c|}
\hline $\begin{array}{ll}\text { Becerinin Adı : Ped kullanma } \\
\text { Amaç } & \text { : Bağımsız olarak ped kullanır. } \\
\text { Malzemeler } & \text { : Ped, su, sabun, havlu } \\
\text { Ortam } & \text { : Banyo } \\
\end{array}$ & & & TUI & SUN & $\mathbf{I L}$ & & \\
\hline Beceri Basamakları & 1 & 2 & 3 & 4 & 5 & 6 & 7 \\
\hline Temiz pedi takar. & & & & & & & \\
\hline 1. Banyoya gider. & & & & & & & \\
\hline 2. Ped paketinden ped alır. & & & & & & & \\
\hline 3. Külodunu indirir. & & & & & & & \\
\hline 4. Pedin bandından tutar. & & & & & & & \\
\hline 5. Pedin bandından tutarak pedin kılıfinı açar. & & & & & & & \\
\hline 6. Pedin kılıfını çöpe atar. & & & & & & & \\
\hline 7. Pedin yapışkan olan yüzeyindeki kağıdı ayırır. & & & & & & & \\
\hline 8. Yapışkan şeklinde olan kağıdı çöpe atar. & & & & & & & \\
\hline 9. Pedi yapışkan olan yüzeyi çamaşıra gelecek biçimde küloduna yerleştirir. & & & & & & & \\
\hline 10. Külodunu çeker. & & & & & & & \\
\hline Kirli pedi çıkarır. & & & & & & & \\
\hline 1. Banyoya gider. & & & & & & & \\
\hline 2. Külodunu indirir. & & & & & & & \\
\hline 3. Pedi çamaşırından ayırır. & & & & & & & \\
\hline 4. Pedi katla/sarar. & & & & & & & \\
\hline 5. Pedi tuvalet kağıdına/ped dışındaki kılıfa sarar. & & & & & & & \\
\hline 6. Pedi çöpe atar. & & & & & & & \\
\hline 7. Yeni ped takar. & & & & & & & \\
\hline 8. Külodunu çeker. & & & & & & & \\
\hline 9. Elini yıkar. & & & & & & & \\
\hline 10. Elini kurular. & & & & & & & \\
\hline Doğru Tepki Sayıs1/Yüzdesi & & & & & & & \\
\hline Yanlış Tepki Sayıs1/Yüzdesi & & & & & & & \\
\hline Tepkide Bulunmama Sayıs1/Yüzdesi & & & & & & & \\
\hline
\end{tabular}




\section{Yoklama Oturumları Veri Kayıt Formu (Devam)}

\begin{tabular}{|c|c|c|c|c|c|c|c|}
\hline $\begin{array}{ll}\text { Becerinin Adı : } & \text { Koltuk altı tüy alma } \\
\text { Amaç } & \text { : Bağımsız olarak koltuk altı tüyleri temizler. } \\
\text { Malzemeler } & \text { : Tüy dökücü sprey, spatula, sünger, su, sabun, havlu } \\
\text { Ortam } & \text { : Banyo }\end{array}$ & \multicolumn{7}{|c|}{ OTURUMLAR } \\
\hline Beceri Basamakları & 1 & 2 & 3 & 4 & 5 & 6 & 7 \\
\hline 1. Banyoya gider. & & & & & & & \\
\hline 2. Spreyi alır. & & & & & & & \\
\hline 3. Spreyin kapağını açar. & & & & & & & \\
\hline 4. Spreyin kapağını lavobonun kenarına bırakır. & & & & & & & \\
\hline 5. Kolunu dirseğin baş hizasına gelinceye kadar kaldırır. & & & & & & & \\
\hline 6. Tüylü bölgeye spreyi sıkar. & & & & & & & \\
\hline 7. Diğer kol altına da sıkar. & & & & & & & \\
\hline 8. $10 \mathrm{dk}$. bekler . & & & & & & & \\
\hline 9. Spatulayı alır. & & & & & & & \\
\hline 10. Spatula ile koltuk altındaki köpüğ̈̈ temizler. & & & & & & & \\
\hline 11. Musluğu açar. & & & & & & & \\
\hline 12. Spatulayı suyun altına tutarak yıkar. & & & & & & & \\
\hline 13. Spatulaya lavabonun kenarına bırakır. & & & & & & & \\
\hline 14. Eline su alır. & & & & & & & \\
\hline 15. Koltuk altını yıkar. & & & & & & & \\
\hline 16. Diğer koltuk altını yıkar. & & & & & & & \\
\hline 17. Koltuk altını kurular. & & & & & & & \\
\hline 18. Ellerini yıkar. & & & & & & & \\
\hline 19. Ellerini kurular. & & & & & & & \\
\hline 20. Musluğu kapatır. & & & & & & & \\
\hline Doğru Tepki Sayısi/Yüzdesi & & & & & & & \\
\hline Yanlış Tepki Sayısi/Yüzdesi & & & & & & & \\
\hline Tepkide Bulunmama Sayısı/Yüzdesi & & & & & & & \\
\hline
\end{tabular}




\section{Ek D}

\section{Anne Sosyal Geçerlik Veri Toplama Formu}

Sayın sizin de deneyimlediğiniz üzere kızınızla kişisel bakım becerilerinden saça şekil verme, tırmak bakımı, ped kullanma ve koltuk altı tüy alma becerilerinin öğretimini gerçekleştirdik. Araştırma dahilinde kızınıza öğretimi yapılmış olan bu beceriler, bu becerilerin öğretiminde kullanılan yöntem ve kızınızın kişisel bakım becerilerini edinmesinin size ve çevresindekilere ne gibi yararlar sağladığını öğrenmek istiyorum. Bu amaçla, yedi tane "evet-hayır", üç tane "açık uçlu" olmak üzere toplam 10 adet sorunun olduğu bir form hazırladım. Hazırlanan soru formunda yer alan soruları yanıtlarken duygu ve düşüncelerinizi titizle ve içtenlikle ifade etmeniz yapılacak çalışmanın amacına yönelik ve doğru olmasına destek verecektir. İlginiz ve katkılarınız için çok teşekkür ederim.

1. Çocuğunuza kişisel bakım becerilerinin öğretiminde aile eğitimi programının önemli olduğunu düşünüyor musunuz?

( ) Evet ( ) Hayır

2. Aile Eğitim Programı'na yönelik olan çalışmaya katılmaktan memnun kaldınız mı?

( ) Evet ( ) Hayır

3. Aile Eğitim Programı'na katılmalarını arkadaşlarınıza önerir misiniz?

( ) Evet Hayır ( )

4. Çocuğunuza kişisel bakım becerilerinin öğretiminde kullandığınız video model yöntemi (kişisel görüş noktası tekniği) sizce çocuğunuz için yararlı oldu mu?

( ) Evet ( ) Hayır ( )

5. Sizce çocuğunuz beceriyi videodan izleyip ardından o beceriyi yapmaktan keyif aldı mı?

( ) Evet ( ) Hayır

6. Çocuğunuza farklı becerileri öğreteceğiniz başka Aile Eğitim Programlarına katılmayı ister misiniz?

( ) Evet ( ) Hayır

7. Öğretimini yaptığınız kişisel bakım becerilerinin çocuğunuzun günlük yaşamda bağımsız yaşam sürdürmeni kolaylaştırdığını düşünüyor musunuz?

( ) Evet ( )Hayır

8. Bu çalışmada sizi mutlu eden durumları söyleyebilir misiniz?

9. Bu çalışmada hoşnut kalmadığınız durumları söyleyebilir misiniz?

10. Katıldığınız Aile Eğitim Programında yer alsaydı daha faydalı olurdu dediğiniz uygulama var midir? 


\section{Ankara University Faculty of Educational Sciences Journal of Special Education}

2022, 23(1), 53-83
RESEARCH

Recieved Date: 22.06 .20

Accepted Date: 06.04.21

OnlineFirst: 26.04.21

\title{
The Effectiveness of a Family Education in Teaching Self-Care Skills to Individuals with Intellectual Disability*
}

\author{
Seniha Kurtoğlu iD 1
}

\author{
Atilla Cavkaytar ${ }^{(D)}$
}

\begin{abstract}
Introduction: Self-care skills are generally learned from one's family in a natural environment such as the home. This study aims to examine the effectiveness of the teaching skills of a mother on her child's acquisition of selfcare skills.

Method: The study was conducted with an 18-year-old individual with intellectual disability (ID) and her 42-yearold mother. The study employed multiple probe design, one of the single-subject research models. The independent variable of the study was the family education program entitled "Self Care Instruction to Individuals with ID". These were the teaching activities carried out by the mother with her child with ID in line with this program. The dependent variable was the level of the individual with ID to fulfill the targeted self-care skills.

Findings: The findings revealed that (a) the instruction given by the mother who completed the family education program on teaching self-care was effective in her child's acquisition of self-care skills, (b) the child was able to generalize the skills acquired to other environments, different individuals and different materials, and (c) the child was able to perform the skills well following the program.

Discussion: Research findings demonstrate that using videos to model instruction on self-care skills is both effective and scientifically based. By the end of the program, the child's performance in all of the self-care skills showed improvement, which meant that the results supported those of previous studies.
\end{abstract}

Keywords: Intellectual disability, family education, self-care skills, video modeling, personal viewpoint technique.

To cite: Kurtoğlu, S., \& Cavkaytar, A. (2022). The effectiveness of a family education in teaching self-care skills to individuals with intellectual disability. Ankara University Faculty of Educational Sciences Journal of Special Education, 23(1), 53-83. https://doi.org/10.21565/ozelegitimdergisi.756223

\footnotetext{
*This study was prepared within the scope of ZEÖ605 Applied Family Education course and presented as an oral presentation at the $29^{\text {th }}$ National Special Education Congress.

${ }^{1}$ Corresponded Author: Teacher, Special Education Vocational School, E-mail: senihakurtoglu37@gmail.com, https://orcid.org/0000-0002-2222-1029

${ }^{2}$ Prof., Maltepe University, Education Faculty, Special Education Department, E-mail: atillacavkaytar@maltepe.edu.tr, https://orcid.org/0000-0001-8067-1602
} 


\section{Introduction}

Since individuals with intellectual disability (ID) need to be prepared to higher stages of education, working life, and society so that they could live independently, it is essential that they gain entirely new sets of skills in addition to improving their current abilities (Cavkaytar, 2000). Educational arrangements need to be made so that such individuals are able to acquire independent living skills which include daily living, academic, and personal-social, and vocational skills (Brolin, 1997; Wandry et al., 2013). Self-maintenance skills, which include self-care skills, are significant parts of independent living skills. Self-maintenance skills can be broken down into different groups, namely, basic ones such as using the toilet, eating, and dressing; the ones that support these basic skills like washing one's hands and face, cleaning one's nose, brushing one's teeth, bathing, and combing one's hair; personal care skills involving skin care, hair care, caring for finger and toe nails, applying makeup, shaving, and menstrual hygiene, and advanced self-maintenance skills such as choosing clothes, taking medication in an appropriate manner, eating healthily along with necessary behaviors to engage in sexual life (Brolin, 1997; Wandry et al., 2013).

Previous studies have found that self-care skills may be acquired through formal and informal means (Purpura et al., 2013; Shanley et al., 2017; Skwarchuck et al., 2014). For example, the skills in question may be learned spontaneously during daily life with the support of same-gendered family members, which may also be realized through a systematic educational process (Aydın \& Cavkaytar, 2019). Acquiring self-maintenance and self-care skills allows an individual to lead a fuller, more independent life. Studies aiming to equip individuals with ID with various independent living skills (e.g., personal grooming) through the support of family members generally include evidence-based family education programs.

Family education seeks to enlighten parents regarding their children's personal characteristics, to teach them ways and methods so that they can help their children acquire various types of knowledge and skills, and to educate them on how they may help their children exhibit a greater set of positive behaviors more frequently while simultaneously decreasing negative behaviors or eliminating them completely (Patterson et al., 2012). Instruction aiming to teach individual with ID the self-maintenance and certain self-care skills is generally conducted by specialists or teachers. However, since individuals with ID spend the greater part of their time with family either at home or in social environments, families play an active and integral role in teaching self-care skills to individuals with ID. Moreover, individuals with ID could engage in personal grooming with the support of adults. However, parents can teach their children the skills mentioned above when appropriate, high-quality opportunities are made available to them (Aydin \& Cavkaytar, 2019).

The current study aims to make contribution to the knowledge and practice of specialists, teachers and parents. Accordingly, the Family Education Self-care Skills Instruction Program is expected to meet the information needs of families regarding how to teach relevant skills to their children at home. The program will be an important example and resource for future studies. It will expand the national and international literature on this field. For these reasons, the need for family education programs in which self-care skills are taught is critical.

This study seeks to determine the effectiveness of a family education program in which a mother used Personal Point-of-View (PPoV) techniques to teach self-care skills to her child. To this end, the answers to the following questions were sought: (a) Did the family education program have an impact on the mother's use of PPoV techniques during instruction? (b) Was the mother's instruction effective in helping her daughter learn selfcare skills? (c) Were the mother and daughter able to maintain their performance of these skills one, two, and three weeks following the end of instruction? (d) Was the individual with ID able to generalize these skills to different settings, instructions, and materials? (e) What were the mother's general attitude and opinions regarding the implementation process?

\section{Method}

\section{Research Model}

There are two dependent variables in this study. First, "the level of realization of the skill steps of the participant mother in teaching personal care skills". The second is "the level of the individual with HA to acquire personal care skills such as nail care, using pads, underarm hair removal and to maintain the skills that they have taught by their mother". 


\section{Participants}

Two participants took part in the study. The first was the individual with Down Syndrome enrolled in $12^{\text {th }}$ grade at a private vocational high school located in Istanbul during the 2018-2019 academic year and the second was her mother. The mother, named Nazik, was a 42-year-old housewife who completed middle school and who was able to read and write. This was the prerequisite for participation in the study. The child's name was Sevgi and was 18 years old. The researcher led the study. A separate researcher analyzed reliability data for the study. Both of these researchers were enrolled in a doctoral program on the education of individuals with ID.

\section{Implementation Process}

The study received ethical approval from Anadolu University (protocol number 21574). During the course of the research, we conducted a total of three one-hour family meetings in which face-to-face educational activities were conducted in addition to a single visit to the house of the individual with ID. This visit lasted one hour and a half. The meetings and home visit lasted as long as required for the mother to teach her daughter the self-care skills to the extent where the study's objectives were achieved. Family meetings were conducted in a classroom within the school in which the student was enrolled. Prior to instructing the mother on how she would use PPoV techniques to teach her daughter self-care skills, we used the Family Education Program Objectives Assessment Form to determine the degree whether she had internalized the study's aim. We proceeded to the instructional family meetings following this assessment.

During the first meeting, the parent was informed about the self-care skills instruction program for families and the content of it, which was then followed by a presentation on independent living, daily life, selfmaintenance, and self-care skills. We began the second meeting by reviewing the home assignments given to the mother in the first meeting and then moved on to an introduction of necessary skills where we also defined the skills to be prioritized, how these skills were to be performed with appropriate reinforcers. We also elaborated on how instruction was planned during this meeting (including the names of skills, research aim, setting, instructional materials, analysis of skills). Data entry forms for probing and instruction sessions were prepared during this meeting. During the third meeting, the explanations on working times, final preparations for pre-instruction, instruction exercises were provided (i.e., attracting attention, presenting skill instructions, types of cues, presenting cues, cue hierarchy, confirmation, reinforcement, execution). The fourth and final meeting included instructional activities concerning an example skill (i.e., hair styling) that the mother was to teach her daughter. During this meeting, the specialist visited the family's home, conducted exercises in the child's natural environment, and offered guidance while working with the family and child. These sessions were video recorded and then watched together to allow for feedback and corrections. Adhering to the steps laid down in the PPoV approach, the mother then worked on this skill with her daughter each day following a two-session format (i.e., one session of instruction, one session of assessment). When the mother expressed that she had obtained consistent data on the example skill in question, the researcher went to the family's home, where she observed performance of the example skill and administered the Family Education Objectives Assessment as a post-test. The experiment process began after his stage, during which the identified skills (i.e., nail care, applying a sanitary pad, shaving one's underarms) were taught following the same steps as the example skill detailed above.

The instruction phase began after obtaining consistent data for the example skill in three consecutive sessions. The entire instruction process involved multiple stages, namely, dealing with the student's initial performance of skills, pre-instruction probing, daily instruction, probing, observation, and generalization. We used the single-opportunity approach to collect probing data on how well the individual with ID was able to perform the skills to be taught prior to the instruction. While using this approach to collect data, the individual was given instructions for the specific target skill. Her actions were appropriately recorded on data collection forms in columns for correct and incorrect responses. The assessment halted at the first instance when the individual received a (-) mark while performing the skill, which led to other steps in the analysis to be marked on the data collection form. This same process was followed for all of the probing sessions.

Data on generalization sessions were evaluated using pre-test and post-tests. These sessions followed the same steps as those in the probing sessions. Pre-test and post-test generalization sessions employed different materials in a different setting with instructions given by different people to practice a different dimension of the skill (toe nail care, using a panty liner, shaving one's bikini line) depending on the skill in question. In generalization sessions, the mother offered verbal reinforcers to her daughter after she successfully performed activities (e.g., "You did a great job!"). 
The observation sessions were organized at home one, two and three weeks after all of the skills were successfully completed by the student and followed the same steps as those during probing sessions. Once the child correctly performed all of the steps of a skill, she was encouraged through verbal and social reinforcers (such as saying "Great job!" or offering her a high five). Furthermore, the specialist who originally worked with the individual came to observe her again one to two months after the completion of the observation stage. The data collected were also used to calculate inter-observer reliability.

In order to ensure inter-observer reliability, a special education specialist (who led the research) collected reliability data. This specialist recorded her observations after watching the mother's performance during probing sessions and implementation. The session recordings were selected randomly. The specialist recorded her observations on data entry forms to generate data on the mother's performance while providing instruction for her daughter.

In the current study, reliability data were collected for the implementation regarding whether the mother was able to utilize PPoV techniques appropriately to teach her daughter how to exercise self-care skills. While calculating implementation reliability, the following behaviors were considered: (a) The preparation of the materials to be used during instruction, (b) how well she offered attention-grabbing cues, (c) her ability to give instructions, (d) demonstrating the video recordings, (e) whether she responded appropriately to her daughter's responses, and (f) her use of reinforcers to motivate her daughter's continuous participation.

Following the conclusion of the study, we asked the mother a set of questions included in a semistructured interview form on the program, the instruction process and its aftermath, the objectives and outcomes of the instruction, the PPoV approach, and the family education program in order to obtain social validity data. Accordingly, we asked the following questions during the interview to the mother: (a) "Do you think that the family education program was important in teaching your child personal grooming skills?" (b) "Are you glad to have participated in the instruction offered by the Family Education Program?" (c) "Would you recommend your friends to participate in the Family Education Program?" (d) Do you think that modeling skills through videos (PPoV) to teach your child personal grooming skills was beneficial for her?" (e) "Do you think your child enjoyed watching and subsequently performing the skill depicted in the video?" (f) "Would you participate in other Family Education Programs designed to teach your child different skills?" and (g) "Do you think that the self-care skills you taught made it easier for your child to live more independently in daily life?"

A performance measurement for pre-test and post-test (i.e., Family Education Program Assessment Measure) designed for the Family Education Self-Care Skills Instruction Program was used to collect data for the mother. Similarly, the Social Validity Question Form was used to collect social validity data. We used entry forms to collect relevant data for the child. Having adopted a multiple probe design, we further needed data on the initial performance levels of how well the individual with ID acquired the self-care skills in question in addition to data for the implementation, probing, and observation sessions. During the implementation stage, we asked the mother to use a pencil to complete the Instructional Process Data Entry Form based on what she expected from the family education program. In the following, she completed the Initial Level, Probing, and Observation Data Entry Forms. Separate entry forms were completed by the mother. These forms were used to collect data during the initial performance level, probing, and observation stages.

\section{Data Collection Tools}

"Data Record Forms for Probing, Instructional and Maintenance Sessions", "Generalization Session Data Record Form" and "Social Validity Form" were prepared. Moreover, "Implementation Reliability Data Record Form for Beginning Level, Probing, Generalization, and Maintenance Sessions" and "Implementation Reliability Data Record Form for Instructional Sessions" were prepared. The first two forms were used for inter-observer reliability data.

\section{Data Collection and Analysis}

While analyzing data related to the family education program, the mother was verbally asked the questions in the Family Education Program Assessment. The answers to these questions were video-recorded for subsequent analysis. Upon conclusion of a session, the practitioner watched the video recording for that particular session and marked the mother's answers to questions using the symbols $(-/+)$. Percentages for the total number of correct answers during the pre- and post-tests were calculated. Pre- and post-test results were compared and analyzed using a column chart. The researcher marked whether items on the control list were realized according to plan or not using a (+) or (-) symbol, respectively. The findings were converted into percentages and analyzed 
in a column chart. Data on the instruction's effectiveness were obtained by recording the number of correct and incorrect responses the child gave to the target skills through PPoV-based instruction and then calculating the percentage for the number of correct responses. Relevant data were collected during daily probing, generalization, and observation sessions organized for the PPoV-based instruction. Regarding data on effectiveness, correct and incorrect responses were first recorded, after which the percentage of correct responses was calculated. Following the study, we prepared the graphical analysis of data. While analyzing inter-observer reliability data, we used the formula "consensus / consensus + divergence x 100" (Tekin-İftar, 2012), which was repeated for each skill. To analyze implementation reliability data, we used the formula entitled "observed practitioner behavior / planned practitioner behavior x 100" (Tekin-İftar, 2012), which was repeated for each skill.

\section{Results}

The results revealed that prior to instruction, Sevgi was initially able to complete skills one, two, and three at a rate of $4 \%, 10 \%$, and $5 \%$, respectively. Over the course of instruction, however, all three of these skills progressed into a rapid improvement. After six sessions of nail care instruction, five sessions of instruction on how to use a sanitary pad, and six sessions on how to shave her underarms, Sevgi was able to complete all of the stages of these skills independently. Similar to data for the instructional process, observation data showed that she performed these skills $100 \%$ of the time. Considering the data, the personal grooming instruction provided by Sevgi's mother, Nazik, was effective. These findings further demonstrated that the instruction of a mother who successfully completed a family education program in self-care instruction designed for individuals with ID was effective in teaching these individuals self-care skills. The reliability findings revealed that inter-observer reliability was $95.6 \%$ for nail care, $97 \%$ for sanitary pad use, and $96.25 \%$ for underarm shaving. The implementation reliability was $93.6 \%$ for nail care, $93.6 \%$ for sanitary pad use, and $92 \%$ for underarm shaving. Findings for social validity revealed that the family education program was an important part of Nazik's instruction of self-care skills to her daughter. The mother was satisfied after participating in the study. She would recommend her friends to participate in the family education program. Furthermore, Nazik found that the PPoV techniques were beneficial. Nazik reported that her daughter significantly enjoyed watching and subsequently self-care the skills depicted in the videos. She told that she would like to attend other family education programs to teach her daughter different skills. She concluded that the self-care skills that she had taught helped her daughter lead a more independent life.

\section{Discussion}

This study examined whether the mother's consistent use of PPoV based-instruction at home had an effect on her daughter's acquisition of self-care skills. The results found that the mother's use of PPoV techniques during instruction were effective in helping her daughter learn the self-care skills. Additionally, we observed that the child continued to demonstrate these skills in a consistent manner one, two, and three weeks following the end of the instruction. Moreover, the mother independently utilized PPoV techniques in a very reliable manner for the instruction.

Research findings in the literature demonstrate that using videos to model instruction on self-care skills is both effective and scientifically based (Hagiwara \& Myles, 1999). Using one type of modeling through video methods, PPoV, the current study found that by the end of the program, the child's performance in all the self-care skills showed progress, meaning that the results of the study supported those of previous studies.

The reason we chose to employ the PPoV approach in this research was because the participating student had highly-developed imitation skills, enjoyed watching videos, and was able to perform the roles given to her and repeating what she had watched in videos, all of which positively impacted her ability to learn skills. Factors facilitating and rendering skills instruction effective included the fact that the participating student was mildly affected by an ID, her willingness to participate in the study once she was explained the reason why she was taught these skills, and the essential nature of these skills in her daily life. As the skills worked on in this study were successive in nature, the individual was prevented from making consecutive mistakes in the same steps during sessions, which also helped her give the correct response to stimuli. The participating student learned additional information which was out of the study's scope: "If you insert the nail clipper as far as it can go, you may cut your fingers,"; "using a nail file helps shape your nails,"; "each sanitary pad uses different kinds of adhesives," and "you should use only a small amount of deodorant under your arm and spray it from a distance." This information, despite not being part of the study's objectives, was extraordinarily helpful in helping the individual acquire and generalize skills. In fact, acquiring this kind of information is vital in helping children make use of independent living skills more effectively. The mother engaged in one-on-one instruction with her daughter in their own home. 
Similar to the results of previous studies in which parents participated in the program (e.g., Cavkaytar, 1998; Özen et al., 2003; Hagiwara \& Myles, 1999), the instruction implemented as part of this program was effective.

However, research on self-care skills instruction with individuals with ID entails several other ethical considerations. For example, our use of the PPoV approach may constitute an area of debate. For privacy-related issues, we had difficulty finding an individual to record instruction sessions where the mother worked with her daughter. We were able to avoid any potential ethical issues with regard to filming PPoV approach-based skills instruction by only recording the execution of the skill itself to a member of the individual's own family following the family's consent.

Whereas previous studies taught self-care skills using a dummy or a doll, the current study taught these skills on the individual. As a result, appropriate clothing was used during skills instruction so as not to violate the participant's privacy. Moreover, instruction on how to use a pad was given during times when the student did not menstruate with underwear worn over a pair of tights. She was taught how to shave her underarms while wearing a sleeveless blouse. Another issue to be addressed was that learning how to care for one's nails, using a pad, and shave one's underarms required extended periods of time. To deal with these issues, we had to use artificial nails during instruction and apply pads during times when the student was not menstruating. While teaching the student how to shave her underarms, we only used foam, believing it to be the safest means possible. It is therefore important that instructors, researchers and practitioners support and encourage families in their attempts to teach their children these skills.

Based on the findings of this study, the following recommendations for future research can be made: (a) programs whose effectiveness on promoting family participation is proven can be increased, (b) teachers can inform families of family education programs and encourage them to participate, (c) families can be made aware of the basic techniques used in special education (e.g., giving instructions, using reinforcers, preparing skill analyses, keeping records); (d) other members of the family (including father, sibling, caretaker, relative) can be involved in the Family Education Program activities, (e) the study can be replicated with families whose children suffer from other deficiencies or families with typically developing children, (f) similar family education programs as the one developed for this study can be created and employed to analyze different independent living skills, and (g) similar programs can be developed and used with parents unable to read and write.

\section{Author's Contributions}

The second researcher guided the first researcher in the process of determining the research subject, literature review and writing the literature, planning the implementation process of the research, analyzing the research data and discussing the results, and reporting the research. The first author conducted the experimental process of the research. The contribution rate of both authors to the research is $50 \%$. 